\title{
The heterogeneous effect of diversity: Ascriptive identities, class and redistribution in developed democracies
}

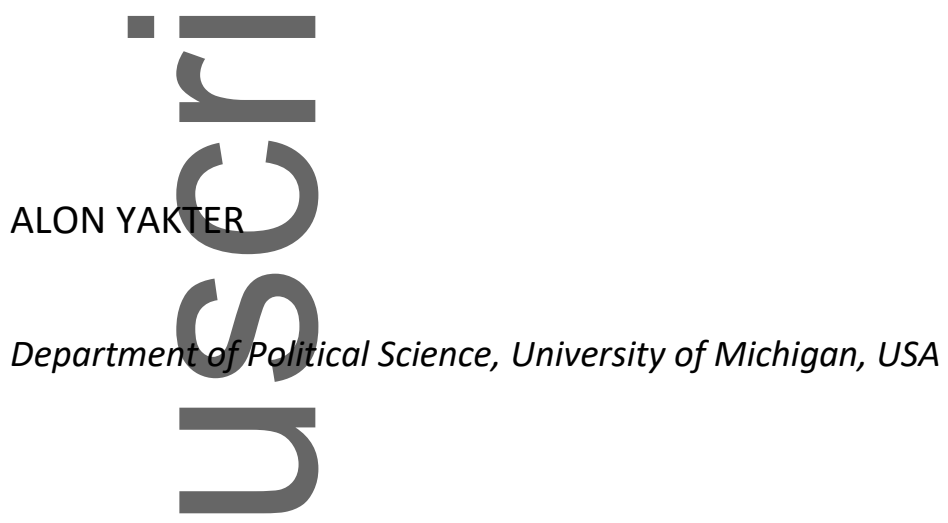

Abstract. The current consensus among comparative political scientists postulates that diverse democracies redistribute less than homogeneous ones. However, whereas homogeneous democracies redistribute more on average, diverse democracies exhibit high variation in (n) redistributive outcomes. Why does ascriptive heterogeneity stifle redistribution in some cases but not in others? In this article, it is argued that diversity undermines redistributive outcomes when identity groups differ more starkly in their income levels. More importantly, under these conditions, the policy outcomes are not uniform: rather than general cutbacks, richer groups selectively under-prioritise benefits and access for poorer, minority-heavy groups while keeping their own redistributive interests protected. The result is not simply less redistribution aggregately, but a more exclusionary and regressive welfare state that prioritises the social needs of better-off identity groups. Empirical support is found for these hypotheses using macrocomparative panel

This is the avent mascript accepted for publication and has undergone full peer review but has not been thi oh th copyediting, typesetting, pagination and proofreading process, which may lead to differences betw this version and the Version of Record. Please cite this article as doi: 10.1111/1475-6765.12283.

This article is protected by copyright. All rights reserved. 
data on multiple redistributive aspects in 22 developed democracies in the years 1980-2011. The article thus outlines a conditional and more nuanced relationship between diversity and redistributive outcomes than commonly assumed, as well as several broader lessons for research of identity politics and social policy.

Keywords: welfare state; redistribution; identity; class; error correction model

Introduction

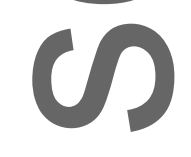

How do ascriptive identity cleavages - ethnicity, race, religion and language - shape redistributive policies in developed democracies? The growing attention to this question by comparative social scientists, and particularly the influential work by Alesina and Glaeser (2004), has cemented the notion that diverse countries redistribute less than homogeneous ones. Yet, although widely accepted, this straightforward theoretical prediction has mixed empirical support, particularly in developed democracies (Mau \& Burkhardt 2009;

Pontusson 2006; Taylor-Gooby 2005). Moreover, newer research on individual-level preferences finds that the negative relationship between diversity and popular support for redistribution depends upon additional demographic and socioeconomic factors (e.g., Alt \& Iversen 2017; Burgoon 2014; Dahlberg et al. 2012; Finseraas 2012).

This article is protected by copyright. All rights reserved. 
Recent descriptive data confirm this empirical tension. Figure 1 plots three different measures of redistribution levels against an index of ascriptive identity fractionalisation ${ }^{1}$ in

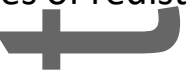

19-22 OECD countries. Figure 1A displays public social spending in 2011 as a share of gross domestic product (GDP), Figure 1B presents the relative reduction in income inequality by tax and transfers in 2011, and Figure 1C showcases the combined generosity of key social security programmes in 2010 (Scruggs 2014). The fitted lines show negative correlations between ascriptive diversity and all three aspects of redistribution. On average, as the literature expects, homogeneous countries spend more than heterogeneous ones on social programmes, reduce a greater share of inequality and offer more generous social security entitlements. However, the plots also reveal a heteroskedastic pattern: whereas homogeneous countries tend to cluster together more closely, heterogeneous ones vary more broadly by all three redistributive measures. This tendency is illustrated with the rox-ch matching box-and-whisker diagrams, which split the sample in half and plot the variation within each subgroup. Thus, the accepted notion that diversity undermines redistribution seems correct but insufficient: higher heterogeneity in ascriptive identities influences redistributive outcomes, but not in all cases. Why is this so?

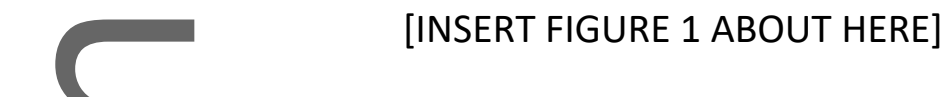

This article addresses this gap by discussing the combined role played by ascriptive identities and class in shaping de facto redistributive outcomes. Building upon previous research on ethnic inequality and redistributive preferences, I argue that diverse democracies redistribute less in practice when some ascriptive identity groups are richer than others and have lower willingness to support the latter. Extending the discussion to This article is protected by copyright. All rights reserved. 
policy outcomes, I hypothesise that the redistributive implications are not uniform. As stronger identity groups seek to minimise intergroup redistribution, the negative effect<smiles>C1CCCCC1</smiles>
concentrates primarily in programmes targeting poorer groups and on the latter's access to social benefits. At the same time, richer groups protect broader redistributive programmes that serve their members and make them more exclusionary. Diversity with higher intergroup inequality, therefore, leads to a more regressive and less inclusive welfare state with more differentiation between the needs it addresses.

I find support in these hypotheses using macrocomparative panel data on multiple redistributive aspects in 22 developed democracies in the years 1980-2011. Specifically, I show that the negative relationship between ascriptive diversity and redistributive outcomes is mediated by the level of income differences between identity groups. More importantly, I find differential outcomes among various redistributive aspects. When identity and income cleavages reinforce one another, higher diversity curbs welfare programmes that target the needs of poorer groups (unemployment, social assistance and public healthcare). However, it does not affect programmes addressing cross-class risks such as old-age and incapacity. Under these conditions, furthermore, key social security programmes cover fewer recipients, even as their generosity per (fully covered) recipient remains high. These combined findings imply higher benefit differentiation between strong (1) and weak groups rather than crude cutbacks across the board. Therein lies the answer to the empirical puzzle: heterogeneous countries tend to redistribute less than homogeneous ones on average, but this tendency varies by the reinforcement of identity and class This article is protected by copyright. All rights reserved. 
divisions and by specific programmes. The article concludes with several broader implications for the study of identity politics and social policy.

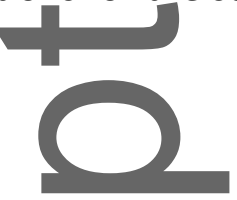

\section{Existing research on diversity, intergroup inequality and} redistribution

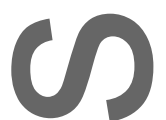

Social scientists have long established that ascriptive identities - ethnicity, race, religion and language - are particularly potent politically given their inherent, indivisible and relatively rigid nature (Lipset \& Rokkan 1967; Rae \& Taylor 1970), their central role in in-group coordination (Bates 1983; Fearon \& Laitin 1996) and their mobilisation by political actors (Chandra 2004; Posner 2004). Different studies have demonstrated that ascriptive identity (20); cleavages influence economic development and democratisation (Easterly \& Levine 1997; Montalvo \& Reynal-Querol 2005), intergroup conflict (Fearon \& Laitin 2003; Wilkinson 2008), public goods provision (Alesina et al. 1999; Habyarimana et al. 2007), party systems (Clark \& Golder 2006; Ordeshook \& Shvetsova 1994) and voter behaviour (Chandra 2004; Huber 2012).

In the same vein, more attention has been given in recent years to the redistributive implications of ascriptive diversity. The accepted wisdom arising from this literature suggests that diverse societies redistribute less income than homogeneous ones. Higher ascriptive heterogeneity, the logic goes, exacerbates collective action problems and fractures class solidarity, leading in turn to more limited welfare policies. Empirical support 
for this argument draws predominantly from the United States, where the salient racial divide is linked repeatedly to reduced public services and social programmes at all levels of ( government (Alesina et al. 1999; Quadagno 1994; Ribar \& Wilhelm 1999; Skocpol 1992). Alesina and Glaeser (2004) offer the most comprehensive comparative presentation of this claim, maintaining that higher racial and ethnolinguistic diversity explains much of the historic gap between the American and European welfare states (see also Desmet et al. 2009; Sanderson 2004). They further argue that ascriptive cleavages precede and explain the emergence of class politics and electoral institutions - the primary drivers of welfare policy according to previous research. The notion that ascriptive heterogeneity weakens redistribution has since become a common premise in comparative politics research.

Although highly influential, this argument has been challenged both theoretically and empirically (for a comprehensive critique, see Pontusson 2006). Taylor-Gooby (2005) and Mau and Burkhardt (2009), for example, argue that the negative correlation loses its statistical power when the sample is limited to Western countries and with a more careful consideration of other economic, political and demographic differences. Furthermore, newer studies find that various individual and social factors condition personal preferences for redistribution in diverse societies (Steele 2016). In particular, researchers found that support in redistribution decreases most strongly when minorities are poorer or perceived rin as such. These studies argue that higher inequality between identity groups increases their perceived social and cultural distance, leading in turn to increased in-group identification (Higashijima \& Houle 2017), decreased solidarity (Lupu \& Pontusson 2011) and stronger stigmatisation of poor minorities (Gilens 1995; Kinder \& Sears 1981; Nelson 1999). 
Intergroup inequality also exacerbates the social threat posed to richer identity groups by generous redistribution, which could mobilise poorer identity groups into the former's (n) communities and undermine their relative social status (Corneo \& Grüner 2002; Shayo 2009). Finally, intergroup income inequality sets apart each group's occupational risks and, accordingly, their redistributive interests (Alt \& Iversen 2017).

Similar mechanisms of intergroup inequality have been linked empirically with higher chances of ethnic voting (Huber \& Suryanarayan 2016) and civil wars (Gubler \& Selway 2012; Østby 2008; Cederman et al. 2011), and with weaker democratic stability (Houle 2015), economic development (Alesina et al. 2016) and public goods provision (Baldwin \& Huber 2010), particularly in developing regions. However, the consequences for redistributive outcomes in democracies remains understudied. The majority of work done on the latter emphasise two, often overlapping, implications, both of which paint only part of the picture (e.g., Alt \& Iversen 2017; Brady \& Finnigan 2014; Burgoon 2014; Finseraas 2012; Stichnoth 2012). First, many studies focus on individual preferences as the primary outcome of interest. Yet, public preferences on redistribution are measured broadly and tell us little about actual policy outcomes. Second, there is increased focus on recent immigration and its mostly negative effect on redistributive preferences and policies. Recent immigrant inflows are an increasingly important factor in Western democracies.<smiles></smiles>
Nevertheless, immigration is one of several causes for ascriptive heterogeneity, and as such is insufficient for a fuller understanding of the latter. New immigrants integrate slowly, do not automatically constitute a coherent political constituency and face unique barriers to full political and economic rights, parliamentary representation and access to state services 
(Bird et al. 2011; Dancygier 2010; Dancygier et al. 2015; Michon \& Vermeulen 2013).

Accordingly, while there are signs of a gradual decline in social spending due to sustained immigration (Soroka et al. 2016), the majority of empirical findings concentrate on immigrant-specific policies such as tighter immigration rules, revised integration policies and stricter immigrant access to welfare programmes (Hemerijck et al. 2013; Koning \& Banting 2013; Sainsbury 2012). Existing theoretical and empirical accounts of the relationship between ascriptive diversity writ large and redistributive outcomes remain incomplete. I turn to addressing this gap next.

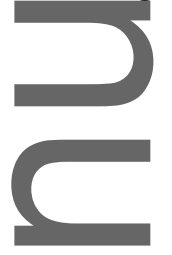

\section{Theoretical propositions: From preferences to redistributive outcomes}

My theoretical propositions on policy outcomes build upon and proceed where the previous discussions stop. Following the literature on ascriptive diversity and redistribution, I expect that heterggeneous democracies would face stronger pressures against broad redistribution than homogeneous ones. But, following the mechanisms outlined in the literature on intergroup inequality and preferences, I expect these forces to vary according to each country's alignment of identity and class. As socioeconomic inequality between identity groups grow, so would they drift apart, identify more strongly with their in-group members and seek to minimise intergroup redistribution. 
These two established premises raise the question of endogeneity in ascriptive cleavages. An influential body of work shows that ascriptive identities can form and

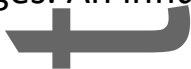

strengthen due to economic development, state borders, electoral institutions and violent conflicts (e.g., Chandra 2004; Laitin 1986; Posner 2005; Sambanis \& Shayo 2013). The discussion in this article adopts a milder position on this issue. On the one hand, I assume that within every country the primary social cleavages have largely been formed long ago - a common claim with regard to contemporary developed democracies (Lipset \& Rokkan 1967). Therefore, I do not explore long-term processes of identity formation within each country. On the other hand, when comparing different countries, the relative political importance of similar identities can differ based on their (slow-changing) cleavage reinforcement with class. The primary comparison here is thus between different social structures rather than within them.

Even as intergroup inequality decreases the motivation for redistribution, the shift from general preferences to policy implications is not straightforward. ${ }^{2}$ Redistributive policy making is not a dichotomous decision between more or less government involvement. To see why, it is useful to consider the two primary roles of the welfare state. First, welfare policies reduce the inequalities created by market forces through income transfer from rich to poor. Second, welfare policies provide social insurance against various socioeconomic (1) risks. Different risks, however, vary in their level of threat to different classes. Some risks, like age-related complications or chronic disability, pose a notable threat to all classes; both rich and poor grow old and may suffer from enduring health problems. Moreover, both aging and chronic disability constitute a particular threat to high-level workers as they 
undermine one's occupational capacity and labour market advantage. By contrast, other risks, like sustained unemployment, material deprivation or sudden short-term healthcare (1)

costs, threaten lower classes more severely. These risks are accommodated more easily by the middle and higher classes, who are in more stable professions, have better access to private insurance and possess higher disposable income and savings. The latter risks, therefore, induce greater interclass redistribution than the former. Following this logic, when somerascriptive identity groups are richer than others, their increased in-group bias should undermine only programmes focused on income redistribution and on lower-class risks. Programmes that protect against shared risks, by contrast, should remain protected as they also benefit middle- and upper-class groups.

Underinvestment in programmes serving the poor is not the only channel through which richer identity groups can minimise intergroup redistribution without hurting their own interests. Another path is to decrease poorer groups' access to programmes that address shared risks. In particular, lower classes can be excluded effectively based on their status in the labour market, where many developed economies experience growing segmentation between different tiers of workers. As research on this topic shows, there is an increasing divergence of interests between so-called 'insider' workers with relatively secure jobs and strong political capital and 'outsider' low-skilled and vulnerable workers oftenr who are often minorities and immigrants (Emmenegger et al. 2012; Iversen \& Soskice 2015; Rueda 2005). Richer groups, therefore, can also entrench harsher access criteria that exclude poorer workers from full labour market protection that they themselves enjoy. 
The theoretical intuition is illustrated in Figure 2, which plots several hypothetical income distributions in a society comprising two ascriptive identity groups. In all cases,

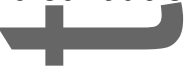

income assumes a standard left-skewed distribution, with a higher concentration of citizens at the middle and lower classes. Panel A plots a perfectly cross-cutting cleavage structure, such that the two identity groups distribute similarly across all income levels. In this case, previous research implies that in-group bias may be weaker, thus moderating its negative effect on redistribution. More importantly, even if each group cares only for the interests of its in-group members, they both share the same risks and benefit similarly from redistributive policies. Accordingly, cutbacks to any programme type will equally hurt both groups. This is not the case when identity and income divisions reinforce one another, as panel B demonstrates. Here, we may expect that the reinforcement of identity and class will increase in-group identification and exacerbate intergroup and interclass distance. Equally int important, in this scenario is that members of the rich identity group benefit nothing from welfare policies targeting the needs of the poor. At the same time, their interest in programmes covering middle- and upper-class needs remains firm. Only in case B can we expect more limited redistributive policies, and specifically those serving the poor.

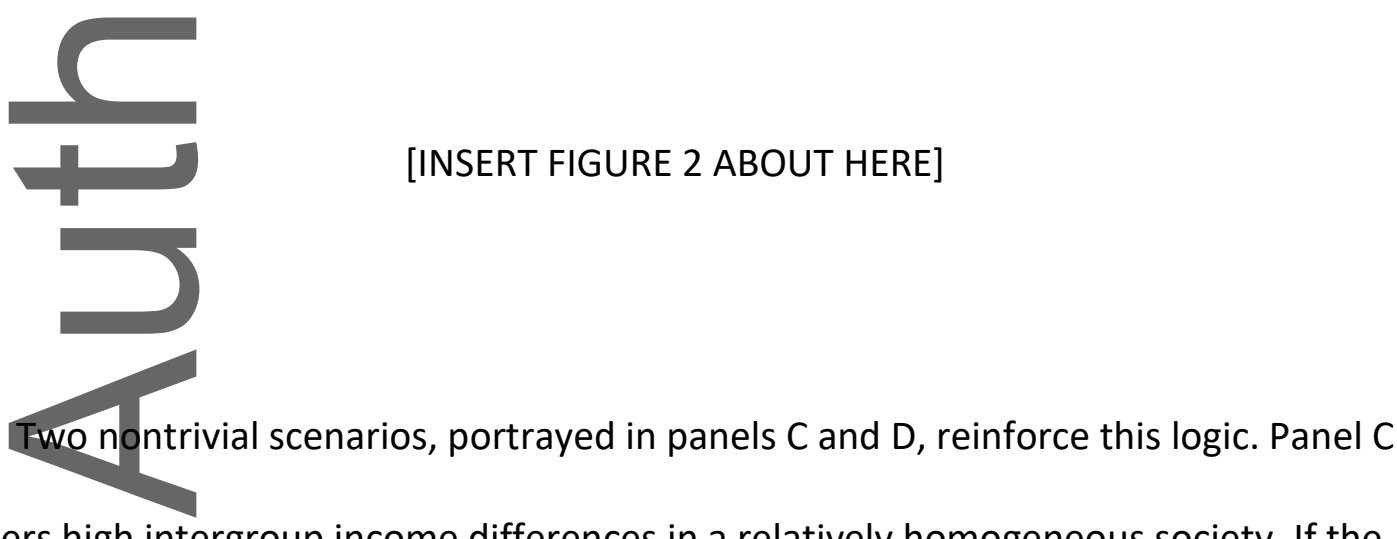
considers high intergroup income differences in a relatively homogeneous society. If the 
poor minority is very small in size, intergroup inequality does not crowd out the dominant group from the lower class. Instead, the majority benefits from all types of welfare policies (1)

regardless of the small minority's position. This example, therefore, underscores that intergroup inequality is insufficient in itself. The key theoretical mechanism requires both higher heterogeneity and stronger reinforcement of identity and class.

Panel D examines a scenario where identity and class cleavages reinforce one another, but now the minority is strictly rich rather than poor. Prima facie, we should expect an opposite outcome compared to panel B, as the poorer majority group could establish a lower-/middle-class coalition that will force the rich minority to redistribute income broadly. This argument, however, is weak for two reasons. First, because of the left-skewed nature of income distributions, in order for a minority to be strictly richer than the lower and middle classes it must be quite small in size. Panel $D$, for example, has the same majority-tominority proportion as in panel C, only with a different spread. Here, too, society is actually quite homogeneous. As it grows more diverse, the minority group's members will fill the ranks of the middle class and fracture the interclass coalition against the rich. Second, even if the rich are a relative minority, a growing literature finds that policy making tends to react more strongly to the interests of the rich (Bartels 2015; Gilens 2012; Peters \& Ensink 2015), implying that a (sufficiently sizable) rich minority would be politically strong even without an absolute majority ${ }^{3}$

In sum, lexpect that higher ascriptive diversity, when reinforced by broader intergroup class differences, will dampen redistributive outcomes nonuniformly, 
concentrating primarily on (1) welfare programmes targeting the needs of the poor, and (2) universal access to programmes providing labour market protection.

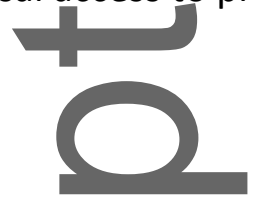

$\square$

\section{Data and empirical strategy}

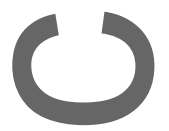

I test these theoretical hypotheses using a series of models estimating how the combination of ascriptive diversity and intergroup income differences correlates with multiple aspects of welfare policy in developed democracies. I use cross-sectional time-series data form the years 1980-2011 for 22 countries: Australia, Austria, Belgium, Canada, Denmark, Finland, France, Germany, Greece, Ireland, Israel, Italy, Japan, The Netherlands, New Zealand, NorwaV, Portugal, Spain, Sweden, Switzerland, the United Kingdom and the United States.

The panel data are unbalanced as not all countries have available data for all years and models.

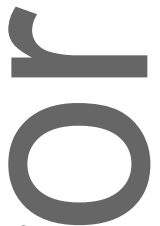

Variables of interest

Dependent variables. I examine the primary outcome of interest - redistribution - from multiple perspectives. The first and simplest aspect is aggregate redistribution levels, measured by two complementary variables: (1) public social spending as a share of GDP, using data from the OECD Social Expenditure Database (SOCX); and (2) relative reduction in income inequality before and after taxes and transfers, measured as the share of change in the Gini coefficient of household income, using data from the Luxembourg Income Survey (LIS; Wang \& Caminada 2011). ${ }^{4}$ The use of two separate measures of redistribution adds robustness to the findings and harnesses each measure's respective strengths. Social spending data are available on an annual basis and for more countries, are better standardised and measure investment in in-kind services in addition to cash transfers.

This article is protected by copyright. All rights reserved. 
Income inequality reduction, meanwhile, captures de facto policy implications and is not as sensitive to economic shocks or recipient numbers as the spending data. All else being equal, I expect that a combination of higher heterogeneity and cleavage reinforcement with class will decrease both measures similarly.

The second aspect unpacks redistribution to subcomponents, again using both public social spending and inequality reduction data. I group disaggregated data from both sources into several categories based on their covered risks ${ }^{5}:(1)$ age-related benefits, consisting of old-age and survivor transfers and services; (2) incapacity and sickness benefits, consisting of sick pay compensation, occupational injury transfers and disability benefits; (3) unemployment benefits, consisting of unemployment compensation and active-labour programmes; (4) assistance benefits, consisting of income maintenance, housing assistance, family and child allowances, and similar in-kind benefits; and (5) public social spending on universal healthcare services. ${ }^{6}$ All else being equal, I expect that a combination of higher heterogeneity and wider intergroup income differences will dampen only unemployment, social assistance and public healthcare programmes, which benefit lower classes disproportionally, whereas old-age and incapacity programmes should not be affected.

The third aspect of redistribution involves inclusiveness in labour market protection programmes. I use data from the Comparative Welfare Entitlement Project (CWED2; Scruggs et al. 2014 on two key social security programmes: unemployment and sick pay insurance. ${ }^{7}$ For each programme, I compare two measures: coverage, measured as the share of labour force insured under each programme: and wage replacement rate, calculated against the mean of an average single worker's wage and an average four-person family's wage. All else being equal, lexpect that a combination of higher heterogeneity and wider intergroup 
income differences will decrease only the level of programme coverage (i.e., access to

programmes), not wage replacement rates (i.e., generosity for those who remain fully

included).
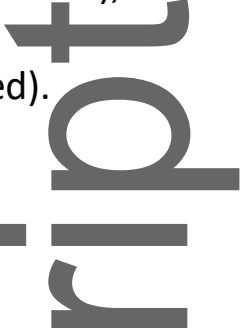

Independent variables. My hypotheses mark two explanatory factors: heterogeneity in ascriptive identities; and the reinforcement of identity and class cleavages. In line with the current literature, I measure ascriptive heterogeneity using one minus the Herfindah/index, which estimates the level of social fractionalisation. ${ }^{8}$ There has been a significant improvement in the quantity and quality of ascriptive fractionalisation indices in recent years. Nevertheless, these indices have two notable problems. First, the multitude of indices raises the risk of post hoc cherry-picking. Second, available indices calculate separate scores for different ascriptive identity dimensions, typically by race, ethnicity, religion and/or language. These different types of identities, however, all share an alleged common genetic, historic or spiritual descent, have relatively rigid and visible criteria, and foster effective social coordination (Chandra 2006; Hale 2004; Haller \& Eder 2015; Laitin 2007). Therefore, this imposed separation makes it difficult to compare similar processes across equally divided countries differing only in the type of active identities that developed there historically (Wimmer 2008). We thus need a common measure to compare the implications of ascriptive intergroup tensions in such cases as the United States (race), Belgium (language), Ireland (religion) or Israel (ethnicity). One way to deal with this problem is to calculate heterogeneity scores based only on each country's politically salient identities (Wimmer et al. 2009). This approach, however, is problematic for my hypotheses, which imply that the political importance of ascriptive identities may vary by its interplay with class. An examination of only politically dominant identities risks obscuring the mediating role of intergroup inequality. To test this relationship, we need a broader measure of heterogeneity in all types of ascriptive identities.
.<smiles>CCCCCCCCC</smiles>
To deal with these problems, I calculate an ascriptive identity fractionalisation (AIF) index that integrates multiple sources and identity types into a single country-score. The 
combination of several sources increases the measure's reliability. I draw from four databases that rely on different types of primary sources: (1) three indices of ethnic, tranch linguistic and religious fractionalisation based on encyclopedic sources (Alesina et al. 2003); (2) the ethnic power relations' (EPR) index of ethnic fractionalisation in politically relevant groups based on expert surveys (Wimmer et al. 2009); (3) the cross-cutting cleavages dataset's two indices of ethnic and religious fractionalisation based on survey data (Selway 2011); and (4) an index of linguistic fractionalisation based on a genealogical linguistic tree analysis (Desmet et al. 2012). I assign equal weight to each identity type: I first average across all indices of a particular dimension, creating separate fractionalisation scores for ethnicity, religion and language, and then average again across all three identity types to produce a single AIF score per country. ${ }^{9}$ Figure 3 summarises the index's structure.

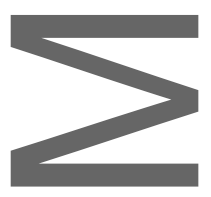
[INSERT FIGURE 3 ABOUT HERE]

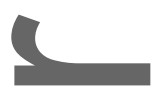

Due to data limitations, the AIF index is time-invariant in that it assigns a fixed score per country for the entire sample period. Although this is not ideal, ascriptive heterogeneity is considered quite stable in the literature, particularly over relatively short periods of 30 or less (Alesin years or less (Alesina et al. 2003: 161). To corroborate this assumption, I recreated the AIF index using data from Patsiurko et al. (2012), who calculate separate ethnic, religious and linguistic fractionalisation scores for 18 of the countries in my sample in 1985 and then in This article is protected by copyright. All rights reserved. 
2000. The strong bivariate correlation between the two periods $(r=0.93, p<0.000)$ implies high stability over time. ${ }^{10}$

The second explanatory variable of interest is the reinforcement of ascriptive identity and income, measured using the cross-cutting cleavages dataset created by Selway (2011), who aggregates data from various public opinion surveys to evaluate the distribution of group members in one cleavage across another. Two cleavages are cross-cutting if the distribution of members along categories in the first cleavage is independent of their distribution in the second. Conversely, two cleavages reinforce one another if their member distributions correlate with one another. Similar to the AIF measure, I average across two ascriptive identity scores in Selway's data: cross-cuttingness of income and ethnicity; and cross-cuttingness of income and religion. ${ }^{11}$ To align with my theoretical hypotheses, I invert the composite score to measure cleavage reinforcement.

Like the AIF index, the cleavage reinforcement scores are time-invariant due to data limitations. This constraint should not pose a fundamental problem, as reinforcement levels are expected to be both exogenous to redistribution and stable during the sample period. For my purposes, the measure's reliance on correlation of distributions across categories is preferable to indices of intergroup income inequality (e.g., Baldwin \& Huber 2010; Houle 2015), which rely on mean incomes that may be endogenous to redistributive policies. Moreover, the surveys used to calculate the reinforcement scores ask responders about their relative income bracket. Redistributive policies lessen inequality (i.e., the gap between income levels and not their position relative to one another) and hence should not affect the latter's distribution. ${ }^{12}$ Several diagnostic and robustness tests, elaborated upon later and in This article is protected by copyright. All rights reserved. 
the Online Appendix, corroborate both the exogeneity and stability of the cleavage reinforcement measure. ${ }^{13}$

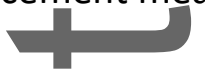

In addition to the two primary variables of interest, I also control for several other explanatory factors associated in the literature with redistributive outcomes. My control variables include institutional features (a combined index of institutional veto points), political power balance (cabinet partisanship and union centrality) and socioeconomic factors (unemployment rate, labour force participation, female participation in the labour force, the share of elderly population, logged trade openness and logged GDP per capita). Appendix Table A 1 summarises the definitions, sources and expected effects of all control variables. The descriptive statistics of the dependent, independent and control variables are presented in the Online Appendix.

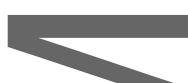

Model specification. My empirical strategy consists of a series of single-equation error-correction models (ECMS) using pooled regression analysis (Beck 1991; Davidson et al. 1978; De Boef \& Keele 2008). Due to indications of panel-specific heteroskedasticity, the estimation employs panelcorrected standard errors (PCSE; Beck \& Katz 1995, 2011). The ECM specification is particularly appropriate for redistribution data, known for their slow change over time and strong serial autocorrelation. This specification assumes that the outcome is in an equilibrium relationship with its explanatory variables, but that this relative stability can be disturbed by short-term shocks followed by a correction back to the long-term trend as the system adjusts. These dynamics are estimated by regressing changes in the dependent variable on the lagged values of all independent variables (long-term equilibrium relationship), the first difference of all dependent variables (shortterm disturbances to the equilibrium) and the lagged value of the independent variable (the correction back to equilibrium). ${ }^{14}$ Since my primary explanatory variables are time-invariant, I include them outside the error-correction dynamics. Their stable values are interpreted as projecting a structural, long-term influence on dynamic patterns of equilibrium and disturbances. Formally, I estimate the following model:

This article is protected by copyright. All rights reserved. 
$\Delta R_{i, t}=\alpha+\beta_{1} \Delta X_{i, t}+\gamma\left(R_{i, t-1}-\beta_{2} X_{i, t-1}\right)+\beta_{3} A I F_{i} \cdot$ Reinforcement $_{i}+\epsilon_{i, t}$

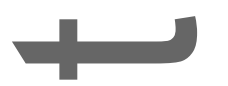

where $B_{1}$ estimates the short-term effect of a vector of control variables $X$ on changes in redistribution level $R, B_{2}$ estimates the long-term effect of a one-unit increase in vector $X, v$ is the error-correction term capturing the speed of adjustment back to equilibrium and 83 estimates the structural effect of my time-invariant explanatory variables. I interact the two main explanatory variables to test their hypothesised conditionality (Brambor et al. 2006;

Kam \& Franzese 2007$).^{15}$

Several alternative model specifications, including a simpler cross-sectional model with a between-effects estimator, support the same theoretical and substantive conclusions. I use the ECM as the baseline specification because it controls for additional variables (unlike a simple cross-sectional model with fewer degrees of freedom) and captures intricate political dynamics by separating stable long-term effects from short-term disturbances (unlike a simpler lagged dependent variable model). I elaborate more on these alternative specifications later in the article and in the Online Appendix.

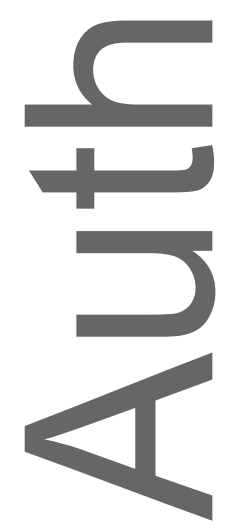

This article is protected by copyright. All rights reserved. 


\section{Findings}

\section{$\sqrt{2}$ \\ Initial premise: Diversity, income and intergroup relations}

Before I turn to my primary analyses of redistributive outcomes, I begin with a simple and higher reinforcement with income undermines group relations and interclass solidarity. To test this assumption, I use data from two cross-sectional surveys with relevant questions. ${ }^{16}$ To examine group relations, I estimate responses to the following question from round 7 of the 2014 European Social Survey (ESS): 'When thinking about contact with different race or ethnic group, in general how bad or good is it?' The answers range on a ten-point scale from 'extremely bad' to 'extremely good'. To examine interclass relations I estimate responses to the following question from the Social Inequality IV module of the 2009 International Social Survey Programme (ISSP): 'In all countries, there are differences or even conflicts between different social groups. In your opinion, in [Respondent's country] how much conflict is there between the working class and the middle class?' The answers range on a four-ppint scale from 'very strong conflicts' to 'there are no conflicts'. I estimate responses to these questions using a multilevel linear regression with random intercepts by country. The models control for individual-level effects of age, sex, education, religiosity and occupational skill level. ${ }^{17}$

The results, presented in Table 1, confirm my theoretical assumptions. Holding individual attributes equal, intergroup contact is experienced more negatively (model 1) and This article is protected by copyright. All rights reserved. 
the poor and middle classes seem in deeper conflict (model 2 ) in countries where ascriptive diversity is reinforced by higher intergroup income differences. With the core theoretical assumptions supported, we can now turn to examining the primary findings on redistributive outcomes.

[INSERT TABLE 1 ABOUT HERE]

\section{Diversity, income and aggregate redistribution}

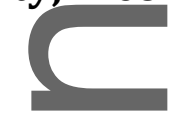

The first set of tests, presented in Table 2, evaluate the prediction that cleavage reinforcement mediates the relationship between ascriptive diversity on redistributive outcomes, which, at this point, is still in aggregate terms. As a point of reference, models 3 and 5 test the direct effect of ascriptive diversity on these outcomes, as proposed by Alesina and Glaeser (2004). Contrary to their argument, I find no direct effect of ascriptive heterogeneity on either social spending or inequality reduction. ${ }^{18}$ Models 4 and 6 , by contrast, support my conditional prediction. The negative interaction coefficients indicate that as the cleavage reinforcement of identity and income grows, ascriptive diversity has an increasingly negative effect on changes in government spending and inequality reduction.

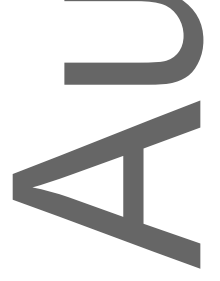

This article is protected by copyright. All rights reserved. 


\section{[INSERT TABLE 2 ABOUT HERE]}

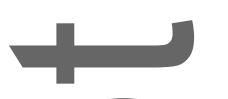

Figure 4 illustrates these patterns visually. The two graphs plot the estimated marginal effect of a hypothetical change from complete homogeneity to complete heterogeneity under different levels of cleavage reinforcement with income. As expected, higher diversity has a negative marginal effect on redistribution, which grows as the two cleavages overlap more closely. Furthermore, the negative influence is significant only past some minimal threshold of cleavage reinforcement. Interestingly, when identity and income cross-cut one another, the spending model estimates that higher heterogeneity will slightly expand redistribution levels. This outcome may be explained theoretically by a race to the top between rival identity groups. When all groups have strong identities and in-group bias, but similar-shares of poor members, increased in-group identification may create simultaneous motivations for higher redistribution to poor in-group peers, increasing overall redistribution as a result. A process in this spirit has been occurring in Belgium since the late-1990s, as both the federal and the regional Flemish governments simultaneously expand overlapping redistributive programmes. This process is fueled to a large degree by the Flemish motivation to establish a separate redistributive system and by federal counteraction to fortify the national system (Béland \& Lecours 2008; Cantillon 2011). This empirical pattern should not be overstated, however, as it is both small in size and does not repeat in inequality reduction. 
[INSERT FIGURE 4 ABOUT HERE]

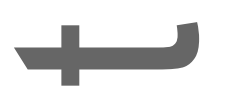

Most, although not all, control variables perform as expected in models 4 and 6 . The relationship with political factors is mixed. Whereas Christian-Democratic cabinets tend to increase redistribution both in the short and long terms, left-leaning cabinets do not display the expected positive correlation. Interestingly, central wage bargaining loses its statistically significant effect once the interaction is added, implying that its direct effect on redistribution is eclipsed not by diversity in itself, but by the latter's juxtaposition with income. The index of institutional veto points also does not have a notable effect.

Among socioeconomic factors, higher unemployment shows a complex pattern: it increases redistribution in the short term, reflecting higher immediate demand, but also reastibut decreases socialspending over the long run, likely due to a shrinking economy and tax base. Higher tabour force participation decreases social spending both immediately and over the long term, although its effect on inequality reduction is insignificant, while higher female participation in the labour force expectedly increases both measures of redistribution. An older population increases social spending in the long run, although it improves inequality reduction only in the short term. More trade openness, associated with opposing pressures on the welfare state, indeed displays a mixed influence: it correlates with short-term reduction in social spending, but also with long-term increase in inequality reduction. GDP growth has the expected positive effect on changes in social spending, for which it acts as the denominator, but not on inequality reduction. Finally, the negative and statistically 
significant error correction terms in all models corroborate the sense of a stable long-term relationship that corrects itself following short-term shocks.

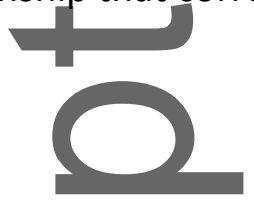

\section{Programme type, coverage and replacement rates}

My hypotheses, nonetheless, expects that diversity and reinforcement with income would exert negative pressures only on social policies serving poorer identity groups. Table 3 presents similar estimations for disaggregated spending and inequality reduction. The results, reported in truncated form for ease of presentation, support my hypotheses: the negative interactive effect of heterogeneity and cleavage reinforcement is statistically significant only for unemployment, social assistance and public healthcare spending - the three programme types that serve lower-class needs most unevenly. By contrast, redistribution for old-age and incapacity - two risks shared by higher classes - remains unaffected by diversity irrespective of its reinforcement levels with income. Importantly, this pattern repeats in both government spending and inequality reduction.

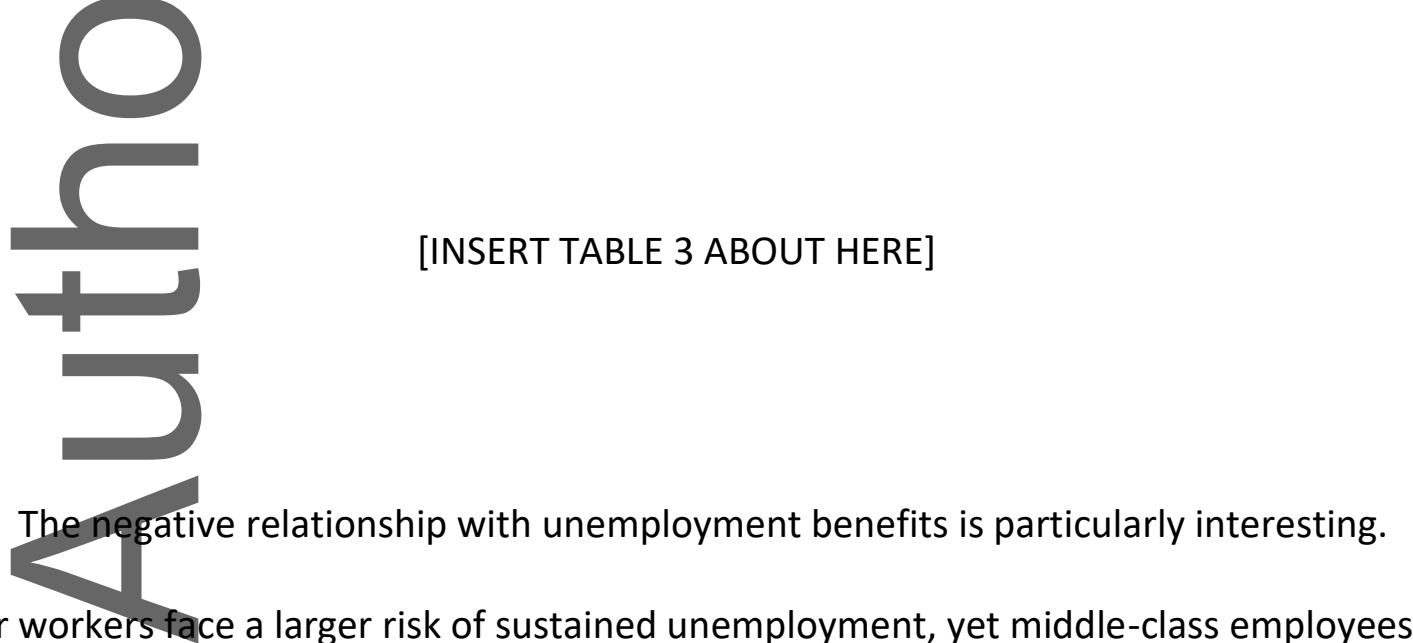


are not fully immune to it. Earlier, I suggested that better-off groups can protect themselves against labour market risks while minimising intergroup redistribution by restricting the

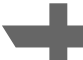
access of poor minorities to social security programmes. Table 4, which estimates changes in levels of coverage and replacement rates, supports this expectation. ${ }^{19}$ Social insurance for both unemployment and sick pay shows the same pattern: the interaction of heterogeneity and cleavage reinforcement has a negative effect on the share of covered workers, but not on the compensation granted to those who are fully included.

\section{[INSERT TABLE 4 ABOUT HERE]}

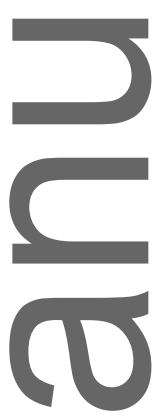

To corroborate that these models reflect exclusion of weaker workers, I also examine whether they predict other labour market policies benefiting strictly stronger workers. I do so by estimating whether the same factors correlate with the OECD's employment protection legislation (EPL) index for individual and collective dismissals of regular contracts, considered a measure of pro-insiders policy in segmented labour markets (Rueda 2005). Since the EPL scores hardly change over time, I ran a cross-sectional model with a between-effects estimator including all the dependent variables from models 16-19. rion The estimation, reported in detail in the Online Appendix, finds a positive and statistically significant interaction coefficient for diversity and reinforcement. In other words, supporting my theory, diverse democracies with higher intergroup inequality tend to protect better-off workers more strongly in other legislation as well. 
The positive interaction effects for replacement rate in Table 4 display a curious trade-off, illustrated visually by the marginal effect plots in Figure 5: higher ascriptive heterogeneity decreases benefit generosity when identity and income cross-cut one another. The reason may be simple budget constraints: to avoid over-spending, wider coverage (under cross-cutting cleavages) may force governments to transfer less per recipient. This interpretation implies that ascriptive diversity and class influence coverage directly andreplacement rates indirectly. When identity and income reinforce one another more strongly, higher heterogeneity leads to narrower coverage and, therefore, to weaker budgetary pressures to cut benefit generosity. When identity and class cut across one another, however, higher heterogeneity motivates all groups to increase inclusion of their members, hence forcing them to reduce benefit generosity to keep the system sustainable.

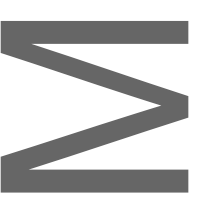
[INSERT FIGURE 5 ABOUT HERE]

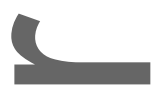

To support the interpretation of a trade-off between coverage and generosity, I reran the same models with the multiplication of coverage and replacement rates as the outcome of interest. If the two indeed trade off, we should find no significant change in rom their combined product regardless of diversity and cleavage structure. The estimation, elaborated upon in the Online appendix, indeed produces the expected null finding.

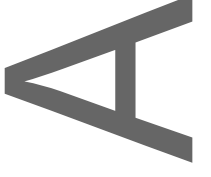

This article is protected by copyright. All rights reserved. 


\section{Robustness checks}

Several diagnostic tests and alternative specifications, all elaborated upon in the Online Appendix, validate the robustness of my findings. First, I cross-validate all models by dropping each country at a time to verify that their fit is not driven by influential cases (Beck \& Katz 2011). I then re-run all models while dropping in turn cases that may stand out for theoretical reasons: Norway, due to its irregular rise in GDP, the denominator of social spending; Greece, due to its partial cleavage reinforcement score (see Note 12); the United States, due to the common critique that its unique racial history and welfare policies drive previous findings; and Israel, due to its extreme cleavage reinforcement score. The findings remain substantively unchanged in all cases.

Second, for models using annual data, I verify that the findings are not driven by the yearly structure of the panel. I do so by replacing the values of all (time-variant) independent variables with their moving averages for the previous three years (i.e., the mean value of lags 1-3) and re-run all models. The results remain substantively unchanged.

Third, I test the model's specification sensitivity by splitting the sample by the median values of each time-varying variable in turn, estimating the primary coefficients on each subsample and averaging their estimates (Athey et al. 2017; Athey \& Imbens 2015). ${ }^{20}$ The mean estimates and their standard deviation support the robustness of my specification.

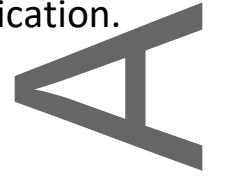

This article is protected by copyright. All rights reserved. 
Fourth, I test my hypotheses using several alternative model specifications.

Specifically, I use a simple cross-sectional between-effects estimator that averages variable for

values for the entire sample period, a standard lagged dependent variable (LDV) model and a minimalLDV model with fewer control variables. Despite their lesser fit to the data, all models corroborate my conclusions.

Finally, Irule out the possibility that the results are driven by an endogenous relationship between redistribution and cleavage reinforcement. As discussed previously, there are both theoretical and empirical reasons that alleviate this concern. Nonetheless, to dispel remaining doubts, I re-run all models with an alternative measure of ethnic inequality created by-Alesina et al. (2016). The ethnic inequality measure maps nighttime satellite imagery of light density, reflecting economic development, onto historic homelands of different ethnic groups within each country. It then calculates a Gini coefficient of inequality in light density between these subnational regions. ${ }^{21}$ This alternative measure is strongly exogenous to redistributive policies, but has two significant weaknesses: first, it refers only to ethnicity; and second, the focus on historic homelands excludes ascriptive cleavages formed through non-geographic processes such as migration, slave trade or religious conversion. Even so, it correlates reasonably well with my cleavage reinforcement measure $(r=0.67, p<0.001)$. The results, reported in more detail in the Online Appendix, r. corroborate my findings.

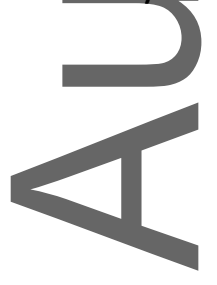

This article is protected by copyright. All rights reserved. 


\section{Conclusion}

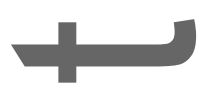

This article has explored when and how ascriptive diversity shapes redistribution in developed democracies. The theoretical and empirical analysis suggests that higher diversity matters for redistributive outcomes, but, contrary to the common assumption, it does not act independently or homogeneously. Instead, extending recent findings on redistributive preferences, I demonstrate that welfare outcomes too are affected by the combination of diversity and class. Specifically, using data from the past few decades, I find that deeper ascriptive diversity dampens redistributive outcomes when income differences between identity groups are sufficiently large and increasing. More importantly, I show that redistributive outcomes are affected nonuniformly. When diversity combines with broad intergroup income differences, politically dominant and richer identity groups selectively cut benefits and access for poorer, minority-heavy groups while keeping their own redistributive interests protected. The result is not fewer social services for everyone, but a more regressive and exclusionary welfare state that prioritises the social needs of better-off identity groups. These findings portray a more nuanced relationship between diversity and redistribution than commonly assumed and shed new light on the unexplained variation in redistribution among heterogeneous countries - the puzzle with which the article started.

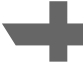

My analysis has several broader contributions to the study of identity politics and social policy. First, the growing body of work and important insights on ethnic politics and individual preferences tell only part of the story. My findings indicate that individual-level mechanisms such as social distance, social rivalry and skill differences imply negative policy This article is protected by copyright. All rights reserved. 
outcomes, but insufficiently so. Individual-level theories, then, should be complemented by macro-level research of actual policy outcomes, the types of available policy tools that can (1) promote them and the conflicting interests that each serves or undermines.

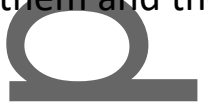

Second, as we turn to consider social policy outcomes, my analysis emphasises the often-overlookedvariation between different types of social policies. Redistributive outcomes are typically analysed aggregately, yet different social policies differ significantly in their underlying goals, target audiences, inclusiveness and implementation. My findings thus point to the importance of additional research on policy design and concrete instruments by which social groups may be differentiated in resource distribution. Furthermore, this avenue of research can shift the theoretical discussion from commonly discussed problems of collective action and solidarity to more nuanced frameworks of competing group interests and unequal allocation of political power.

Third, longstanding cleavage structures are important for the rapidly growing debate on recent immigration and its influence on social policy. My analysis implies that identity politics did not begin with current migrant inflows, but rather have long influenced redistributive patterns. As such, it is fair to assume that recent changes in the ascriptive makeup of developed democracies build upon previous intergroup dynamics and policy equilibria. More attention should thus be given to the interaction of new and old identity divisions, intergroup coalitions and rivalries, and intergroup power balance. Heterogeneous countries whose social policies are already shaped in light of old ascriptive tensions may deal differently with incoming immigration compared to more homogeneous welfare states, and, moreover, new immigrants may alter the mutual affinities and interests of old This article is protected by copyright. All rights reserved. 
ascriptive identity groups. Recent immigration, in other words, is the newest development in the ongoing dynamics of identity politics in the developed world.

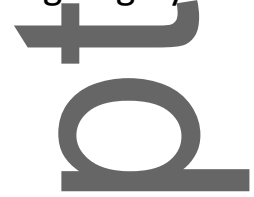

\section{Acknowledgements}

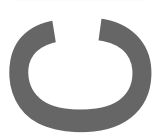

The author is grateful to Diogo Ferrari, Rob Franzese, Noam Gidron, Anna Grzymala-Busse, Johannes Karreth, Traute Meyer, Rob Mickey, Michael Shalev, Lior Sheffer and two anonymous reviewers for their insightful comments and suggestions. All errors remain my own. This work was supported by the Horowitz Foundation for Social Policy.

\section{Appendix}

[INSERT APPENDIX TABLE A1 ABOUT HERE]

\section{Notes}

1. The ascriptive identity fractionalisation (AIF) index integrates multiple data sources and identity dimensions, including ethnicity, religion and language. I elaborate upon its operationalisation in later sections of this article.

2. For simplicity, I assume that re-election-seeking politicians always promote the interests of identity groups within their electoral coalitions. In the discussion that follows, therefore, I refer directly to identity groups as the key political actors. 
3. Empirically, it is hard to find many current instances of small but dominant minorities in contemporary developed democracies. Examples of privileged minorities in in contempors

developing regions, typically the result of colonial legacies, do indicate strong protection of their economic interests (e.g., whites in South Africa, ethnic Russians in former Soviet republics or ethnic Chinese in various Southeast Asian countries).

4. The LIS data do not include Japan, New Zealand and Portugal. In addition, the LIS data are not annual and spaced unequally over time by country. When analysing these data, I therefore follow Persson et al. (2007: 19) and Lupu and Pontusson (2011: 324 ) in averaging the values of annual independent variables for the period between every two country observations.

5. My disaggregation leaves out several components that are theoretically irrelevant on their own. In the OECD expenditure data, I exclude the 'other' category since, as the name implies, its content varies by country. In the LIS data, I exclude military service and veteran transfers.

6. There is no LIS data on public healthcare, which largely involves public services rather than direct cash transfers that affect individual income.

7. The CWED2 data do not include Israel.

$$
\text { r }
$$

8. The index is calculated as $=1-\sum_{i=1}^{G} p_{i}^{2}$, where $p i$ is the relative share of group $i$ in the general population and $G$ is the total number of groups. Substantively, the index 
reflects the odds that two randomly selected members of a given society belong to different groups.

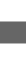

9. Most indices count race under ethnicity, so it is not included separately. Although they rely on different primary sources, the different indices correlate strongly along their respective identity dimensions.

10. There are, of course, growing immigration inflows to Western democracies in recent years. However, this should not destabilise the AIF scores significantly during my sample period. First, immigrant populations arriving by the mid-2000s are included in my data. Second, later immigration is relatively gradual: with few exceptions, annual immigration inflow rates leading to 2011 are less than 1 per cent of the host population. Indeed, the bivariate correlation between the AIF index and foreign-born population shares in 2011 (OECD data) is relatively high $(r=0.66, p<0.005)$. Third, newer immigrants are not absorbed immediately into the cleavage structure and the political system, and should thus influence policy making quite slowly. Nevertheless, I re-ran all my models with an additional control for annual immigration inflows as a share of the population (OECD data). Despite a smaller sample size, my findings remain robust.

11. Selway (2011) counts linguistic groups under ethnicity. Additionally, Greece has no data on ethnicity/income cross-cuttingness, but I nonetheless keep it in the sample using only its religion/income cross-cuttingness score. Ethnicity plays only a minor role in Greece: its combined ethnic fractionalisation score is 0.076 compared to a 
sample mean of 0.22 . As a robustness check, I omitted Greece from all my models and found substantively unchanged results.

12. This premise does not imply that ascriptive identities and class are ossified indefinitely, only that socioeconomic structures change very slowly, if at all, due to prolonged processes involving investment in human capital, education and infrastructure. Furthermore, intergroup perceptions and stigmas - a central mechanism behind group preferences - change even slower.

13. To test for exogeneity, I re-ran my models with an alternative measure of group inequality instead of cleavage reinforcement and found substantively similar results. This test is elaborated upon later in this article and in the Online Appendix. To test for stability over time, I analysed the cleavage reinforcement scores in 97

comparable surveys conducted by the same data-collecting project, in the same country, using the same question wording, but in different years. I then calculated the annual difference rate between all comparable survey dyads. The results rule out the existence of a consistent pattern of temporal change in the relationship between identity and income. This procedure is explained in detail in the Online Appendix.

.14 Lagrange multiplier tests indicate that the ECM structure decreases, but not eliminates, serial autocorrelation when estimating annual spending data. To solve this problem, I add the lagged first difference of the dependent variable $(\Delta R i, t-1)$ and of its denominator $(\triangle G D P i, t-1)$. The first difference of the dependent variable (but not of GDP) is also added when estimating unemployment coverage, 
diagnosed with a similar problem. This fix eliminates the remaining serial autocorrelation.

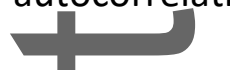

15. As a robustness check, I re-ran my models with the alternative bin-estimator approach for interactions suggested by Hainmueller et al. (2016). Where their code executes, their procedure supports my findings. Additional details are reported in the Online Appendix.

.16 These surveys do not include all relevant countries: the European Social Survey, as implied by its name, includes only the European countries from my sample (with the addition of Israel); the relevant module of the International Social Survey

Programme does not include Canada, Greece, Ireland and the Netherlands.

17. Age is measured using six age groups. Sex is measured using a dummy variable indicating whether respondents are female. Education is measured as respondents' highest level of education. Religion is measured as frequency of attendance at religious services. Skill level is measured using the International Standard Classification of Occupations' four skill levels based on respondents' ISCO-08 occupation classification.

18. To verify that this null result is not an artifact of my AIF measure, I re-ran models 1 and 3 using Alesina and Glaeser's original ethnic, linguistic and religious fractionalisation measures. None of their indices produce a statistically significance result. 
19. Models 16-19 include union density as an additional control variable (collinearity with central wage bargaining is ruled out) since some countries employ a Ghent with central system, where social security services are distributed by labour unions rather than a state agency. Therefore, union membership is expected to have a direct mechanical effect on labour market coverage. Central wage bargaining is preferred elsewhere due to better data availability. As a robustness check, I re-ran all other models with union density instead of central wage bargaining and found substantively unchanged results despite a smaller sample.

20. I use the median values in 1997 - the first year in the panel in which I have a balanced sample for all variables. My nine time-varying covariates produce 18 subsamples for the subsequent estimations.

21. Tuse scores from 1992 (the earliest available year) based on data from Georeferencing of Ethnic Groups (GREG). Ethnic groups smaller than 1 per cent of the

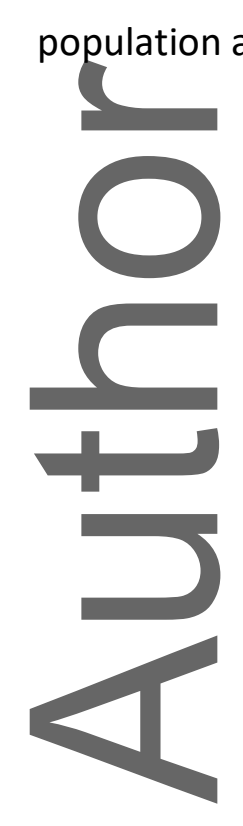

This article is protected by copyright. All rights reserved. 


\section{References}

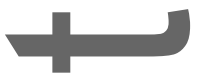

Alesina, A. \& Glaeser, E.L. (2004). Fighting poverty in the US and Europe: A world of difference. Oxford: Oxford University Press.

Alesina, A., Baqir, R. \& Easterly, W. (1999). Public goods and ethnic divisions. Quarterly Journat of Economics 114(4): 1243-1284.

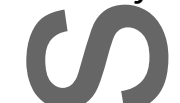

Alesina, A., Michalopoulos, S. \& Papaioannou, E. (2016). Ethnic inequality. Journal of Political Economy 124(2): 428-488.

Alesina, A et al. (2003). Fractionalization. Journal of Economic Growth 8: 155-194.

Alt, J. \& Iversen,T. (2017). Inequality, labor market segmentation and preferences for redistribution. American Journal of Political Science 61(1): 21-36.

Athey, S. \& Imbens, G. (2015). A measure of robustness to misspecification. American Economic Review: Papers and Proceedings 105(5): 476-480.

Athey, S. et al. (2017). Estimating average treatment effects: Supplementary analyses and remaining challenges. American Economic Review: Papers and Proceedings 107(5):

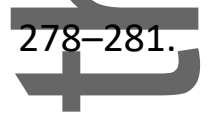

Baldwin, K. \& Huber, J.D. (2010). Economic versus cultural differences: Forms of ethnic diversity and public goods provision. American Political Science Review 104(4): 644662 
Bartels, L.M. (2015). The Social Welfare Deficit: Public Opinion, Policy Responsiveness and Political Inequality in Affluent Democracies. Paper presented at the 22nd I

International Conference of Europeanists, Paris, 8-10 July.

Bates, R.H. (1983). Modernization, ethnic competition and the rationality of politics in contemporary Africa. In D.S. Rothchild \& V.A. Olorunsola (eds), States versus ethnic claims: African policy dilemmas. Boulder, CO: Westview Press.

Beck, N. (1991).Comparing dynamic specifications: The case of presidential approval.

Political Analysis 3: 51-87.

Beck, N. \& Katz, J.N. (1995). What to do (and not to do) with time-series cross-section data. American Political Science Review 89(3): 634-647.

Beck, N. \& Katz, J.N. (2011). Modeling dynamics in time-series-cross-section political economy data. Annual Review of Political Science 14: 331-352.

Béland, D. \& Lecours, A. (2008). Nationalism and social policy: The politics of territorial solidarity. New York: Oxford University Press.

Bird, K., Saalfeld, T. \& Wüst, A.M. (eds) (2011). The political representation of immigrants and minorities: Voters, parties and parliaments in liberal democracies. New York: Routledge.

Brady, D. \& Finnigan, R. (2014). Does immigration undermine public support for social policy? American Sociological Review 79(1): 17-42. 
Brambor, T., Clark, W.R. \& Golder, M. (2006). Understanding interaction models: Improving empirical analyses. Political Analysis 14: 63-82.

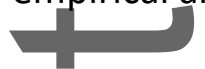

Burgoon, B. (2014). Immigration, integration and support for redistribution in Europe. World Politics 66(3): 365-405.

Cantillon, B.(2011). On the possibilities and limitations of a layered social security system in Belgium: Considerations from a social efficacy perspective. In B. Cantillon, P. Popelier \& N.Mussche (eds), Social federalism: The creation of a layered welfare state - The Belgian case. Portland: Intersentia.

Cederman, L.-E., Weidmann, N.B. \& Gleditsch, K.S. (2011). Horizontal inequalities and ethnonationalist civil war: A global comparison. American Political Science Review $105(3): 478-495$.

Chandra, K. (2004). Why ethnic parties succeed: Patronage and ethnic head counts in India. New York: Cambridge University Press.

Chandra, K. (2006). What is ethnic identity and does it matter? Annual Review of Political Science 9(1): 397-424.

Clark, W.R. \& Golder, M. (2006). Rehabilitating Duverger's theory: Testing the mechanical and strategic modifying effects of electoral laws. Comparative Political Studies 39(6):

$679-708$.

Corneo, G \& Grüner, H.P. (2002). Individual preferences for political redistribution. Journal of Public Economics 83(1): 83-107. 
Dahlberg, M., Edmark, K. \& Lundqvist, H. (2012). Ethnic diversity and preferences for redistribution. Journal of Political Economy 120(1): 41-76.

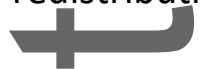

Dancygier, R.M. (2010). Immigration and conflict in Europe. New York: Cambridge University

Press.

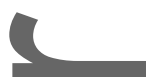

Dancygier, R.M.et al. (2015). Why are immigrants underrepresented in politics? Evidence from Sweden. American Political Science Review 109(4): 703-724.

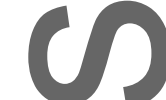

Davidson, J.E.H. et al. (1978). Econometric modelling of the aggregate time-series

relationship between consumers' expenditure and income in the United Kingdom.

Economic Journal 88(352): 661-692.

De Boef, S. \& Keele, L. (2008). Taking time seriously. American Journal of Political Science 52(1): 184-200.

Desmet, K., Ortuño-Ortín, I. \& Wacziarg, R. (2012). The political economy of linguistic cleavages. Journal of Development Economics 97(2): 322-338.

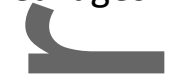

Desmet, K., Ortuño-Ortín, I. \& Weber, S. (2009). Linguistic diversity and redistribution. Journal of the European Economic Association 7(6): 1291-1318.

Easterly, W. \& Levine, R. (1997). Africa's growth tragedy: Policies and ethnic divisions. Quarterly Journal of Economics 112(4): 1203-1250.

Emmenegger, P. et al. (2012). The age of dualization: The changing face of inequality in deindustrializing societies. New York: Oxford University Press. 
Fearon, J.D. \& Laitin, D.D. (1996). Explaining interethnic cooperation. American Political Science Review 90(4): 715-735.

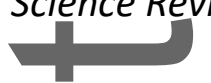

Fearon, J.D. \& Laitin, D.D. (2003). Ethnicity, insurgency and civil war. American Political

Science Review 97(1): 75-90.

(

Finseraas, $H$ (2012). Poverty, ethnic minorities among the poor, and preferences for

redistribution in European regions. Journal of European Social Policy 22(2): 164-180.

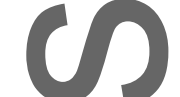

Gilens, M. (1995). Racial attitudes and opposition to welfare. Journal of Politics 57(4): 994-

1014

Gilens, M.(2012). Affluence and influence: Economic inequality and political power in

America. Princeton, NJ: Princeton University Press.

Gubler, J.R. \& Selway, J.S. (2012). Horizontal inequality, crosscutting cleavages and civil war. Journal of Conflict Resolution 56(2): 206-232.

Habyarimana, J. et al. (2007). Why does ethnic diversity undermine public goods provision?

American Political Science Review 101(4): 709-725.

Hainmueller, J., Mummolo, J. \& Xu, Y. (2016). How much should we trust estimates from

multiplicative interaction models? Simple tools to improve empirical practice.

Available online at: http://papers.ssrn.com/abstract=2739221

Hale, H.E. (2004).Explaining ethnicity. Comparative Political Studies 37(4): 458-485.

This article is protected by copyright. All rights reserved. 
Haller, M. \& Eder, A. (2015). Ethnic stratification and economic inequality around the world:

The end of exploitation and exclusion? Burlington, VT: Ashgate.

.

Hemerijck, A.C. et al. (2013). Changing European welfare states and the evolution of migrant

incorporation regimes: Background paper reviewing welfare state structures and

reform dynamics in a comparative perspective. Oxford: IMPACIM.

47

Higashijima, M. \& Houle, C. (2017). Ethnic inequality and the strength of ethnic identities in sub-Saharan Africa. Political Behavior. DOI: 10.1007/s11109-017-9430-8.

Houle, C. (2015). Ethnic inequality and the dismantling of democracy: Evidence from sub-

Saharan Africa and beyond. World Politics 67(3): 469-505.

Huber, J.D.(2012). Measuring ethnic voting: Do proportional electoral laws politicize ethnicity? American Journal of Political Science 56(4): 986-1001.

Huber, J.D. \& Suryanarayan, P. (2016). Ethnic inequality and the ethnification of political parties: Evidence from India. World Politics 68(1): 149-188.

Iversen, T. \& Soskice, D. (2015). Democratic limits to redistribution: Inclusionary versus exclusionary coalitions in the knowledge economy. World Politics 67(2): 185-225.

Kam, C.D. \& Franzese, R.J. (2007). Modeling and interpreting interactive hypotheses in regressionanalysis. Ann Arbor, MI: University of Michigan Press.

Kinder, D.R. \& Sears, D.O. (1981). Prejudice and politics: Symbolic racism versus racial threats to the good life. Journal of Personality and Social Psychology 40(3): 414-431. 
Koning, E.A. \& Banting, K.G. (2013). Inequality below the surface: Reviewing immigrants' access to and utilization of five Canadian welfare programs. Canadian Public Policy

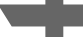

39(4): 581-601.

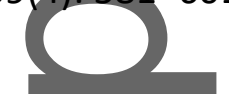

Laitin, D.D. (1986). Hegemony and culture: Politics and religious change among the Yoruba.

Chicago, IL: University of Chicago Press.

Laitin, D.D. (2007). Nation, states and violence. Oxford: Oxford University Press.

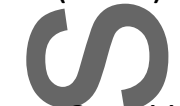

Lipset, S.M. \& Rokkan, S. (1967). Cleavage structures, party systems and voter alignments:

An introduction. In Party systems and voter alignments: Cross-national perspectives.

\section{London: Free Press.}

Lupu, N. \& Pontusson, J. (2011). The structure of inequality and the politics of redistribution. American Political Science Review 105(2): 316-336.

Mau, S. \& Burkhardt, C. (2009). Migration and welfare state solidarity in Western Europe. Journal of European Social Policy 19(3): 213-229.

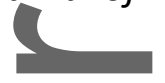

Michon, L. \& Vermeulen, F. (2013). Explaining different trajectories in immigrant political integration: Moroccans and Turks in Amsterdam. West European Politics 36(3): 597-

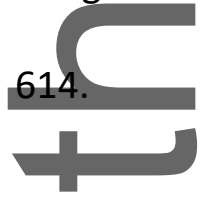

Montalvo,J.G. \& Reynal-Querol, M. (2005). Ethnic diversity and economic development. Journal of Development Economics 76(2): 293-323.

This article is protected by copyright. All rights reserved. 
Nelson, T.E. (1999). Group affect and attribution in social policy opinion. Journal of Politics 61(2): 331-362.

(61): 3 .

Ordeshook, P.C. \& Shvetsova, O. V. (1994). Ethnic heterogeneity, district magnitude and the number of parties. American Journal of Political Science 38(1): 100-123.

Østby, G. (2008). Polarization, horizontal inequalities and violent civil conflict. Journal of Peace Research 45(2): 143-162.

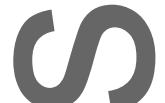

Patsiurko, N., Campbell, J.L. \& Hall, J.A. (2012). Measuring cultural diversity: Ethnic, linguistic and religious fractionalization in the OECD. Ethnic and Racial Studies 35(2): 195-217.

Persson, T., Roland, G. \& Tabellini, G. (2007). Electoral rules and government spending in parliamentary democracies. Quarterly Journal of Political Science 2(2): 155-188.

Peters, Y.\&Ensink, S.J. (2015). Differential responsiveness in Europe: The effects of preference difference and electoral participation. West European Politics 38(3): 577600.

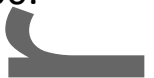

Pontusson, J. (2006). The American welfare state in comparative perspective: Reflections on Alberto Alesina and Edward L. Glaeser, 'Fighting Poverty in the US and Europe'. Perspectives on Politics 4(2): 315-326.

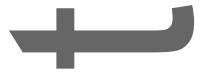

Posner, D.N. (2004). Political salience of cultural differences: Why Chewas and Tumbukas are allies in Zambia and adversaries in Malawi. American Political Science Review 98(4): 529-545.

This article is protected by copyright. All rights reserved. 
Posner, D.N. (2005). Institutions and ethnic politics in Africa. New York: Cambridge

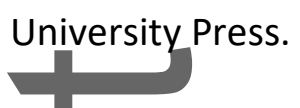

Quadagno, J. (1994). The color of welfare: How racism undermined the war on poverty. New

York: Oxford University Press.

1

Rae, D.W. \&Taytor, M. (1970). The analysis of political cleavages. New Haven, CT: Yale

University Press.

12

Ribar, D.C. \& Withelm, M.O. (1999). The demand for welfare generosity. Review of

Economics and Statistics 81(1): 96-108.

Rueda, D. (2005). Insider-outsider politics in industrialized democracies: The challenge to social democratic parties. American Political Science Review 99(1): 61-74.

Sainsbury, D. (2012). Welfare states and immigrant rights: The politics of inclusion and

exclusion. Oxford: Oxford University Press.

Sambanis, N. \& Shayo, M. (2013). Social identification and ethnic conflict. American Political

Science Review 107(2): 294-326.

Sanderson, S.K. (2004). Ethnic heterogeneity and public spending: Testing the evolutionary

theory of ethnicity with cross-national data. In F.K. Salter (ed.), Welfare, ethnicity

and altruism: New data and evolutionary theory. Portland, OR: Frank Cass.

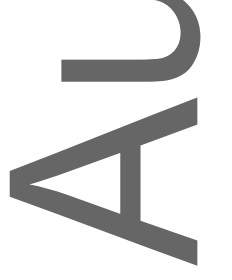

This article is protected by copyright. All rights reserved. 
Scruggs, L. (2014). Social welfare generosity scores in CWED 2: A methodological genealogy.

CWED Working Paper 1. Available online at:

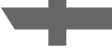

http://cwed2.org/Data/CWED2_WP_01_2014_Scruggs.pdf

Scruggs, L, Jahn, D. \& Kuitto, K. (2014). Comparative Welfare Entitlements Dataset 2.

Version 2014-03. Available online at: http://cwed2.org/

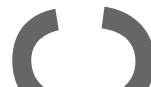

Selway, J.S. (2011). The measurement of cross-cutting cleavages and other multidimensional cleavage structures. Political Analysis 19(1): 48-65.

Shayo, M.(2009). A model of social identity with an application to political economy:

Nation, class and redistribution. American Political Science Review 103(2): 147-174.

Skocpol, T.(1992). Protecting soldiers and mothers: The political origins of social policy in the United States. Cambridge, MA: Belknap Press.

Soroka, S.N. et al.(2016). Migration and welfare state spending. European Political Science Review 8(2): 173-194.

Steele, L.G. (2016). Ethnic diversity and support for redistributive social policies. Social Forces 94(4): 1439-1481.

Stichnoth, H. (2012). Does immigration weaken natives' support for the unemployed?

Evidence from Germany. Public Choice 151(3): 631-654.

This article is protected by copyright. All rights reserved. 
Taylor-Gooby, P. (2005). Is the future American? Or, can left politics preserve European welfare states from erosion through growing diversity? Journal of Social Policy 34(4):

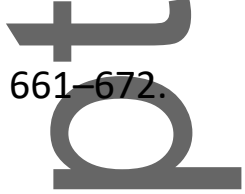

Wang, C. \& Caminada, K. (2011). Disentangling income inequality and the redistributive

2011.02 Leiden: Department of Economics Research, University of Leiden.

Wilkinson, S.1. (2008). Which group identities lead to most violence? Evidence from Africa. In

S.N. Kalyvas, I. Shapiro \& T. Masoud (eds), Order, conflict and violence. New York:

Cambridge University Press.

Wimmer, A. (2008). The making and unmaking of ethnic boundaries: A multilevel process

theory. American Journal of Sociology 113(4): 970-1022.

theor

Wimmer, A., Cederman, L.-E. \& Min, B. (2009). Ethnic politics and armed conflict: A configurational analysis of a new global data set. American Sociological Review 74(2):

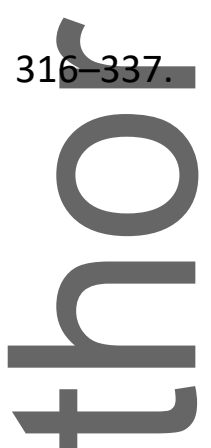

Address far correspondence: Alon Yakter, Department of Political Science, University of Michigan, 5700 Haven Hall, 505 S. State Street, Ann Arbor, MI 48109, USA. E-mail:

ayakter@umich.edu

This article is protected by copyright. All rights reserved. 
(A) Public Social Spending, 2011

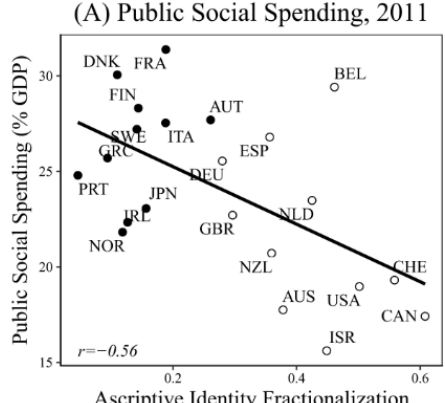

(B) Reduction in Inequality, 2011
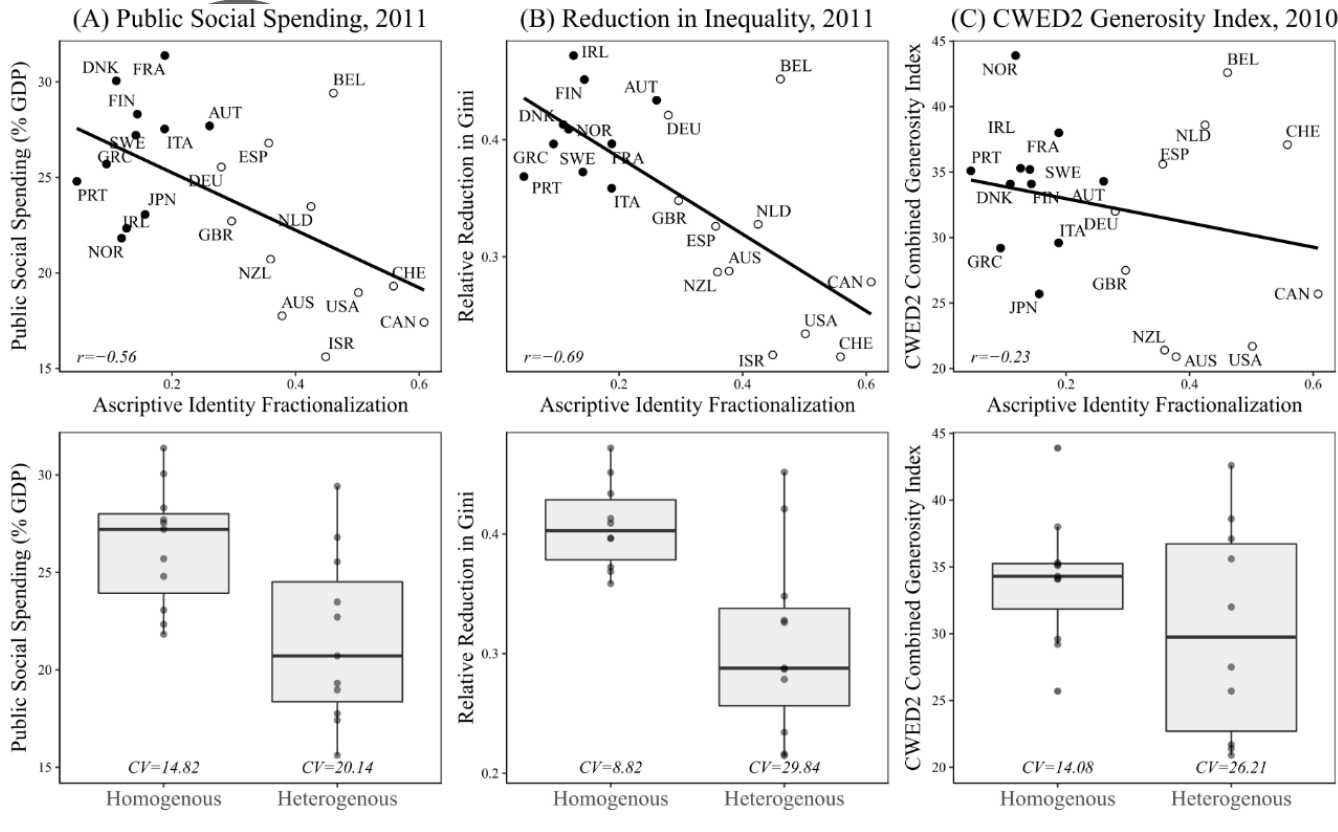

Ascriptive Identity Fractionalization

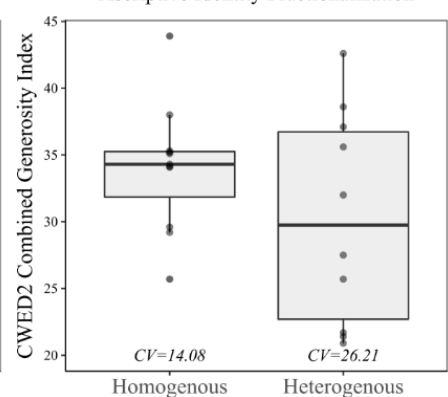

- Homogeneous ○ Heterogeneous

Figure 1 . Ascriptive diversity and three measures of redistribution. CV designates the subgroup's coefficient of variation.

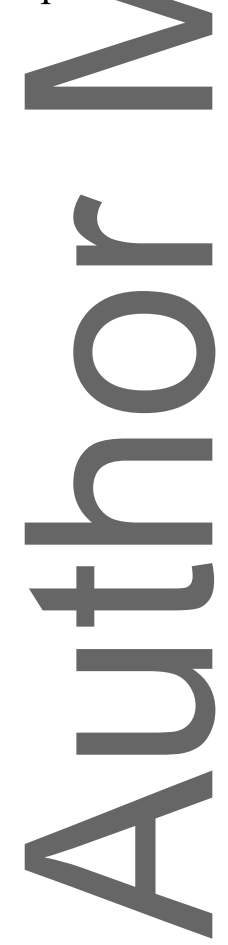

This article is protected by copyright. All rights reserved. 
(A) Cross-Cutting Cleavages

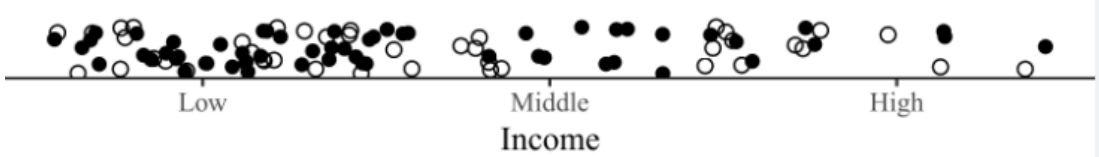

(B) Reinfocring Cleavages (Heterogeneous Society)

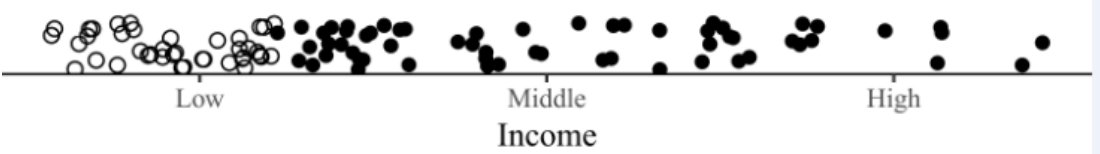

(C) Reinforcing Cleavages (Homogeneous Society)

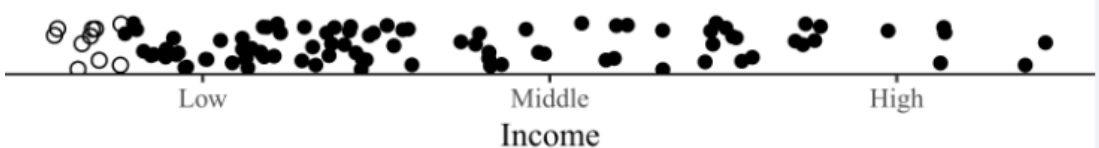

(D) Reinforcing Cleavages (Rich Minority)

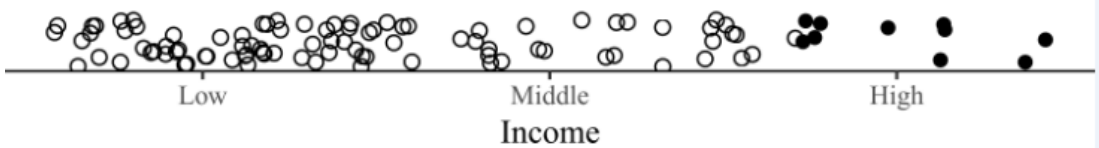

- Identity group 1 Identity group 2

Figure 2. Identity and income distributions under different cleavage structures.

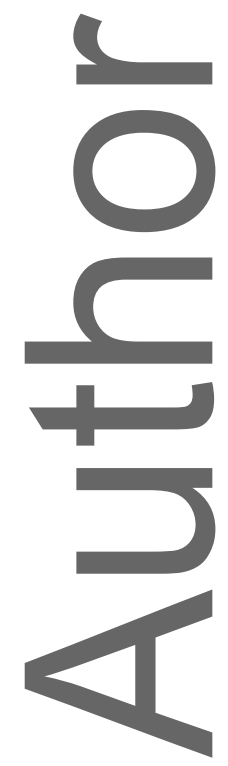

This article is protected by copyright. All rights reserved. 


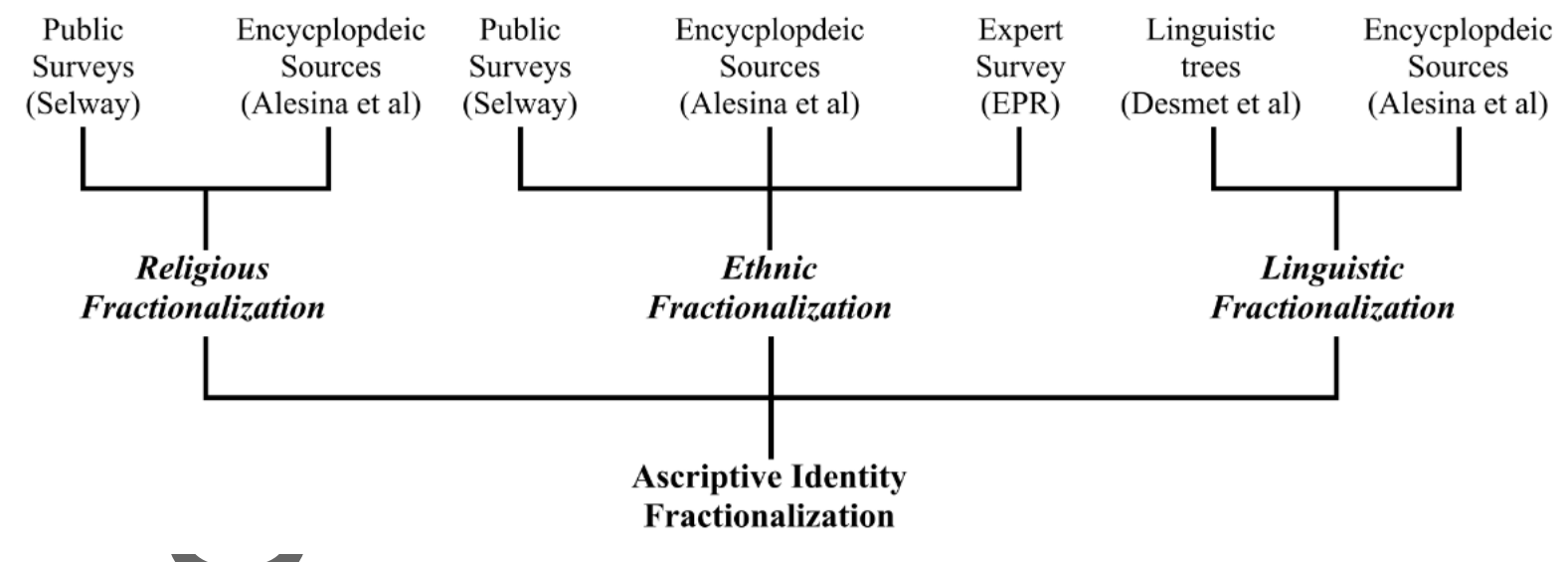

Figure 3. The ascriptive identity fractionalisation (AIF) index.

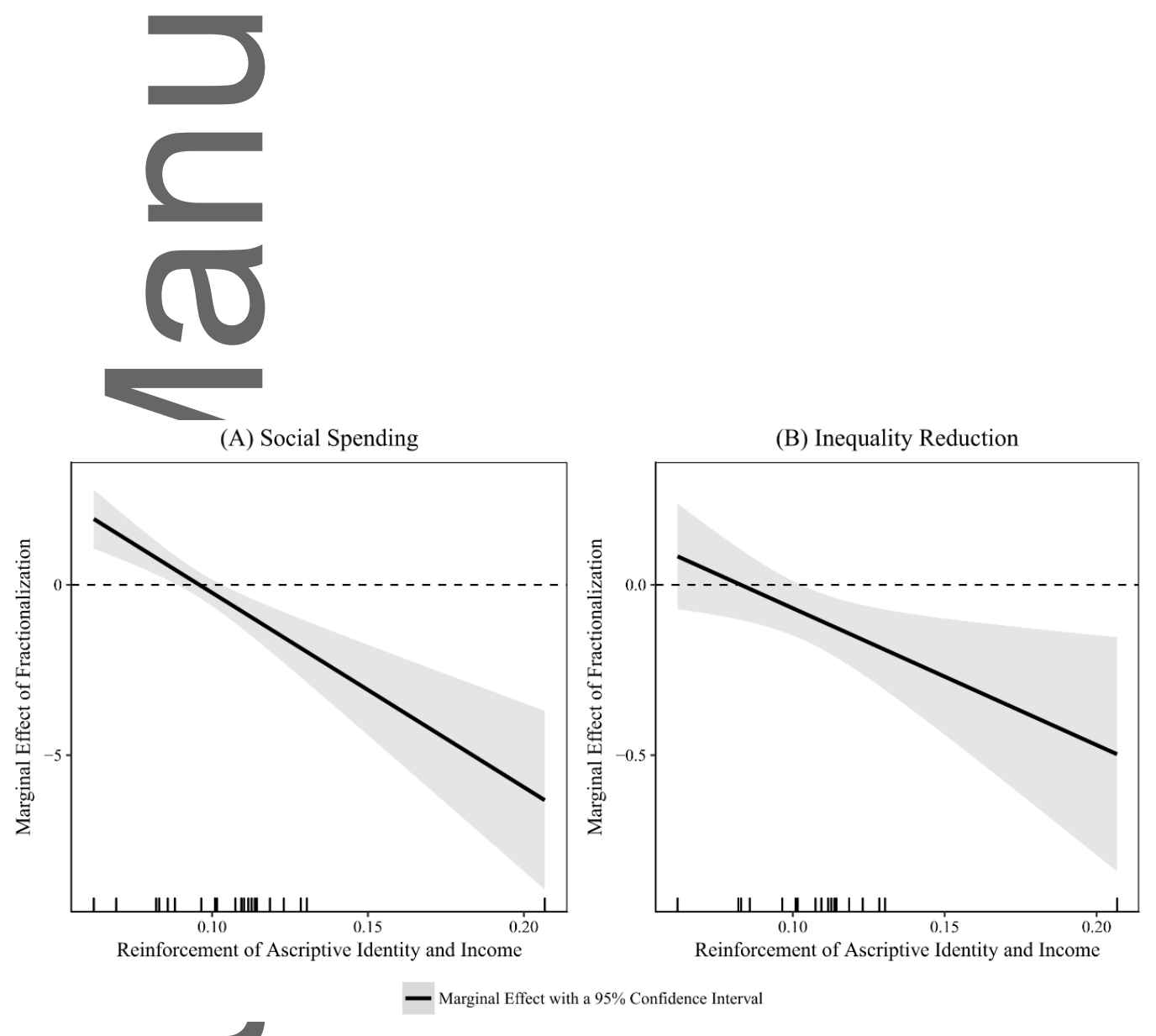

Figure 4. The marginal effect of ascriptive diversity on overall redistribution conditional on income reinforcement.

This article is protected by copyright. All rights reserved. 
(A) Unemployment

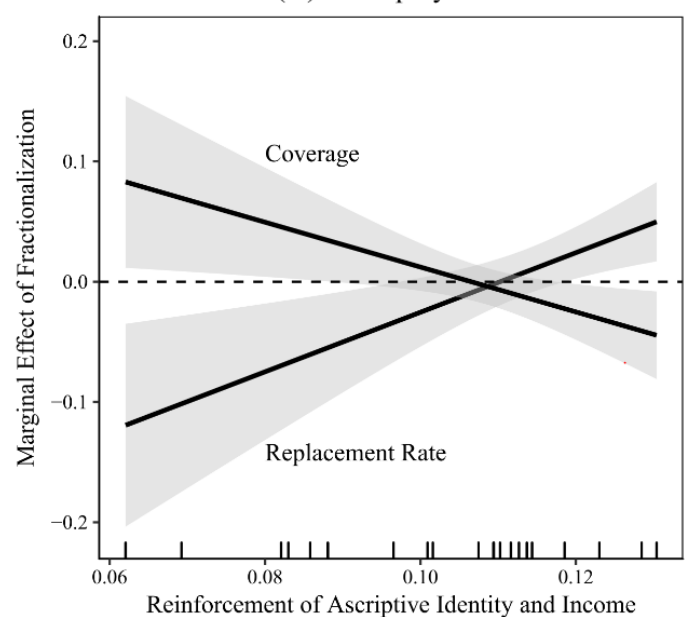

— Marginal Effect with a 95\% Confidence Interval
(B) Sick-Pay Insurance

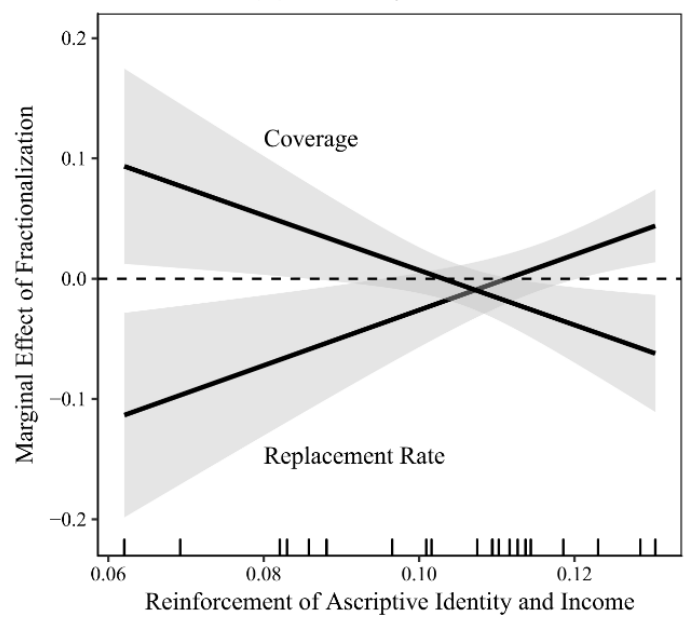

$\overline{\mathrm{O}}$

Figure 5. The marginal effect of ascriptive diversity on social security coverage and replacement rates conditional on income reinforcement.

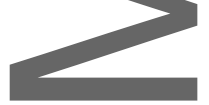

Appendix Table A1. Control variables for redistribution: Definitions, sources and expected effect

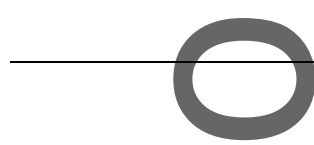

Expected

\begin{tabular}{l|lll} 
Variable & Definition & Data source & sign \\
\cline { 2 - 3 } & Additive veto points index: (1) degree of & Armingeon et al. 2016 & +
\end{tabular}

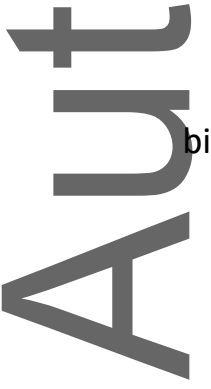

federalism; (2) presence of

presidentialism; (3) degree of

bicameralism; (4) use of referenda; (5)

degree of proportionality; and (6)

presence of judicial review

This article is protected by copyright. All rights reserved. 


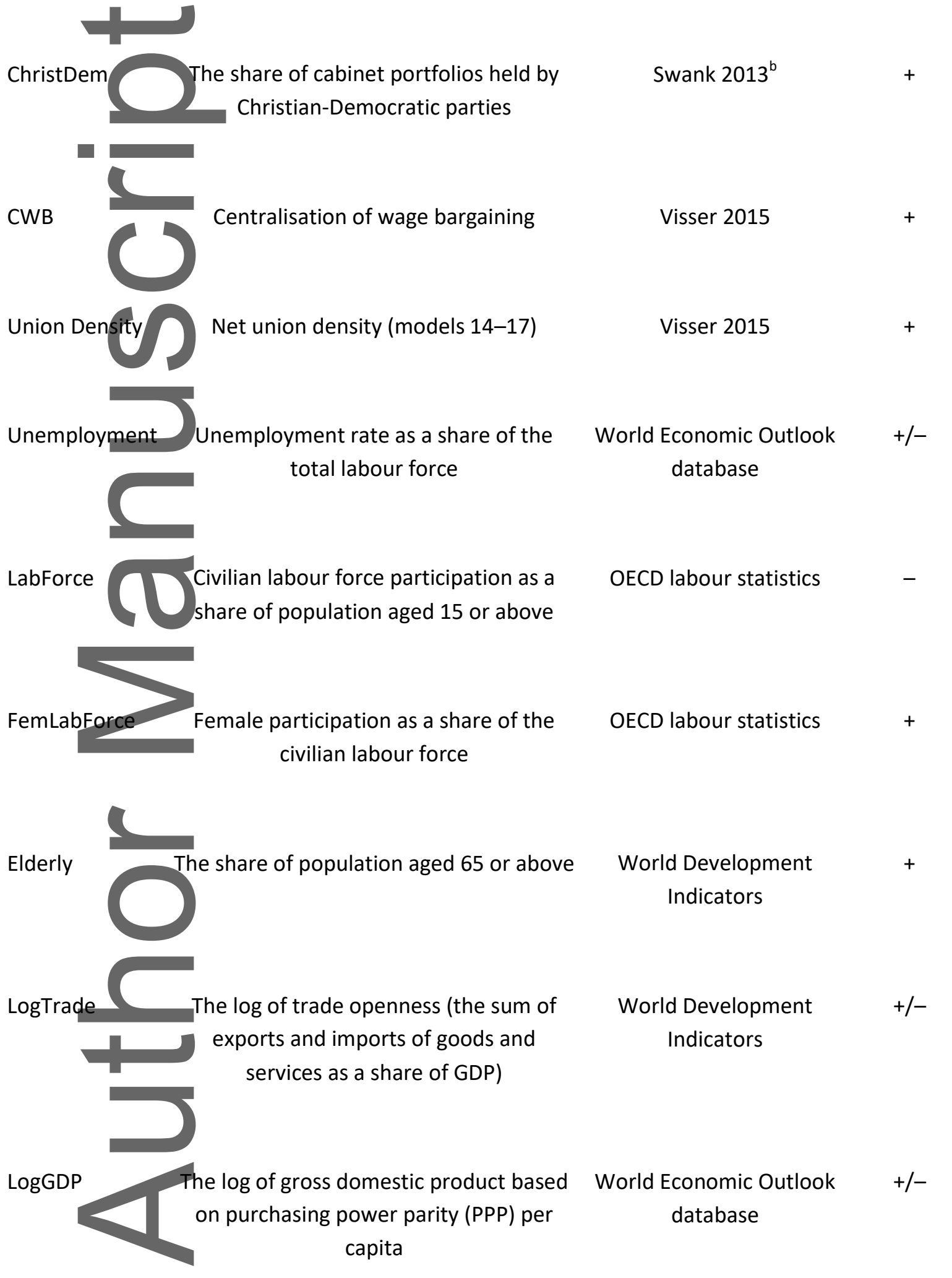

This article is protected by copyright. All rights reserved. 
Notes: ${ }^{a}$ I code Israel's values using the same rules as Armingeon et al. as it is missing from the original dataset. ' Since Israel is missing from Swank's database, I the same coding rules to calculate the cabinet portfolio allocation for left parties in Israel using data from the European Journal of Political Research Political Data Yearbook. Israel does not have Christian-Democratic parties.

Table 1. The interactive effect of diversity and income reinforcement on intergroup relations

\begin{tabular}{|c|c|c|}
\hline & $\begin{array}{c}\text { (1) } \\
\text { Positive contact }\end{array}$ & $\begin{array}{c}\text { (2) } \\
\text { Interclass accord }\end{array}$ \\
\hline \multicolumn{3}{|l|}{ Country-level } \\
\hline AlF & $7.737^{* * *}(2.145)$ & $2.811^{*}(1.485)$ \\
\hline Reinforcement & $27.944^{* * *}(7.693)$ & $12.766^{* *}(5.128)$ \\
\hline AlF*Reinforce & $-70.572^{* * *}(18.049)$ & $-27.665^{* *}(12.601)$ \\
\hline Age group & $-0.055^{* * *}(0.009)$ & $0.013^{* *}(0.007)$ \\
\hline Female & $0.045(0.032)$ & $-0.089^{* * *}(0.014)$ \\
\hline Education & $0.064^{* * *}(0.020)$ & $0.044^{* * *}(0.007)$ \\
\hline Religiosity & $-0.035(0.027)$ & $-0.007^{* *}(0.003)$ \\
\hline Skill level & $0.110^{* * *}(0.020)$ & $0.038^{* * *}(0.009)$ \\
\hline Constant & $3.697^{* * *}(0.849)$ & $1.508^{* * *}(0.568)$ \\
\hline Random intercept variance (country) & $0.048^{* * *}(0.019)$ & $0.023^{* * *}(0.009)$ \\
\hline Residual & $3.507^{* * *}(0.158)$ & $0.426^{* * *}(0.009)$ \\
\hline
\end{tabular}

This article is protected by copyright. All rights reserved. 
Observations

Countries

AIC

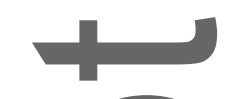

23,561

15

97,131
16,931

17

33,306

Notes: ${ }^{*} p<0.1 ;{ }^{* *} p<0.05 ;{ }^{* * *} p<0.01$. Standard errors in parentheses.

Table 2. The interactive effect of diversity and income reinforcement on social spending and on inequality reduction

\begin{tabular}{|c|c|c|c|c|}
\hline & \multicolumn{2}{|c|}{ Overall spending } & \multicolumn{2}{|c|}{ Inequality reduction } \\
\hline & (3) & (4) & (5) & (6) \\
\hline AlF & $-0.241(0.214)$ & $4.389^{* * *}(1.144)$ & $-0.062(0.045)$ & $0.389^{* * *}(0.126)$ \\
\hline Reinforceme & & $18.495^{* * *}(4.712)$ & & $1.158^{* *}(0.567)$ \\
\hline AIF*Reinfor & & $-45.767^{* * *}(11.898)$ & & $-4.066^{* * *}(1.339)$ \\
\hline Veto & $0.001(0.018)$ & $-0.001(0.018)$ & $-0.001(0.004)$ & $-0.003(0.004)$ \\
\hline Short-term & & & & \\
\hline$\Delta$ Left & $0.001(0.001)$ & $0.000(0.001)$ & $-0.000(0.000)$ & $-0.000(0.000)$ \\
\hline$\Delta$ ChristDem & $0.008^{* *}(0.004)$ & $0.009^{* *}(0.004)$ & $0.001^{* * *}(0.000)$ & $0.001^{* * *}(0.000)$ \\
\hline$\triangle C W B$ & $0.032(0.050)$ & $0.025(0.050)$ & $0.006(0.008)$ & $0.006(0.008)$ \\
\hline$\Delta$ Unemp & $0.135^{* * *}(0.037)$ & $0.127^{* * *}(0.037)$ & $0.004^{* *}(0.002)$ & $0.005^{* * *}(0.002)$ \\
\hline$\Delta$ LabForce & $-0.167^{* * *}(0.042)$ & $-0.175^{* * *}(0.042)$ & $-0.004(0.005)$ & $-0.004(0.004)$ \\
\hline$\Delta$ FemLabFo & $0.329^{* * *}(0.089)$ & $0.309^{* * *}(0.087)$ & $0.010(0.010)$ & $0.008(0.010)$ \\
\hline$\triangle$ Pop65 & $0.188(0.202)$ & $0.443^{* *}(0.218)$ & $0.029^{* * *}(0.011)$ & $0.033^{* * *}(0.012)$ \\
\hline$\Delta$ LogTrade & $-1.728^{* * *}(0.558)$ & $-1.615^{* * *}(0.547)$ & $0.043(0.067)$ & $0.027(0.062)$ \\
\hline$\Delta \log G \mathrm{DP}$ & $-17.400^{* * *}(2.013)$ & $-17.854^{* * *}(1.983)$ & $0.041(0.092)$ & $0.019(0.089)$ \\
\hline
\end{tabular}

This article is protected by copyright. All rights reserved. 


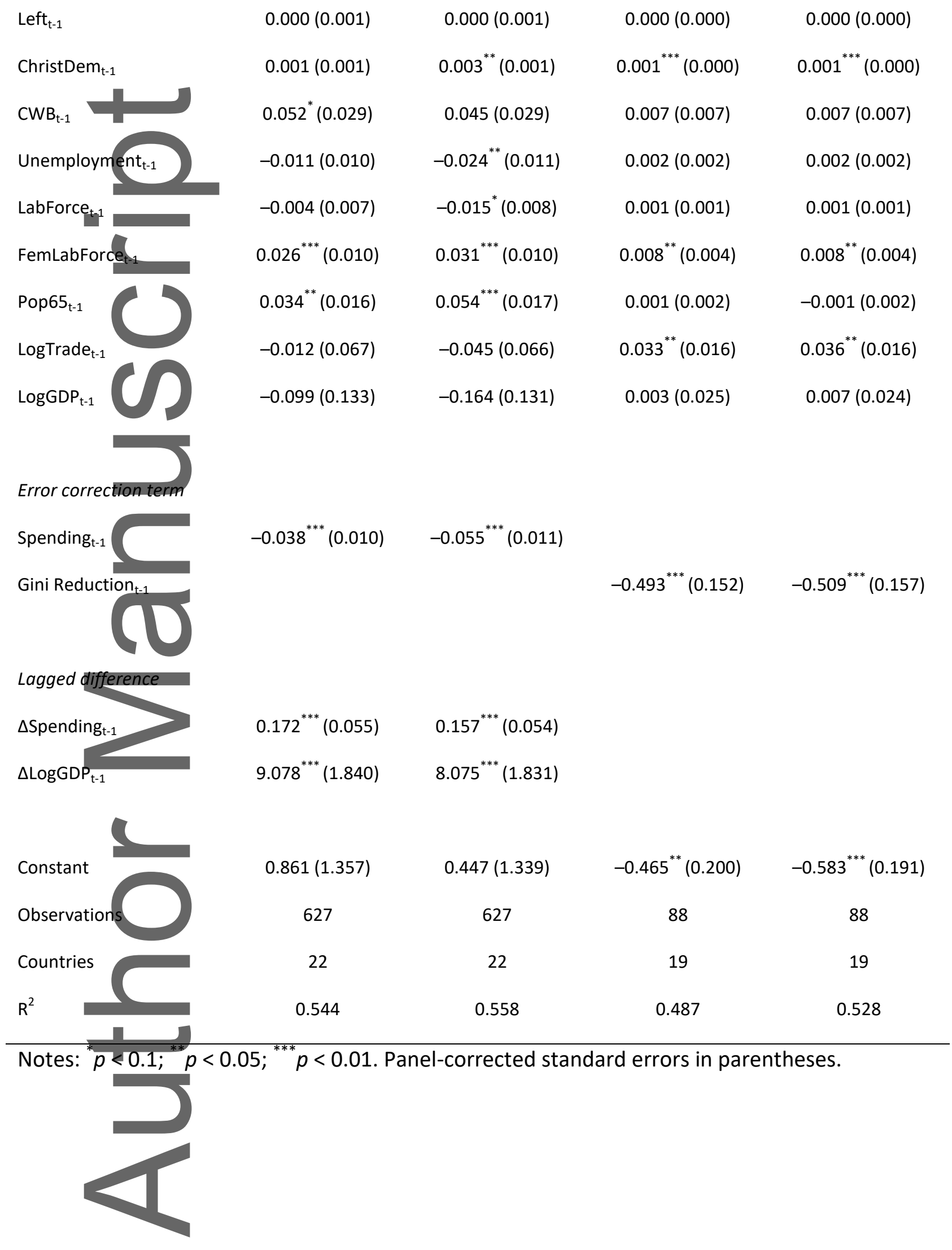

This article is protected by copyright. All rights reserved. 
Table 3. The interactive effect of diversity and income reinforcement by programme type

\begin{tabular}{|c|c|c|c|c|c|}
\hline \multirow{3}{*}{$\square$} & \multicolumn{5}{|c|}{ Public social spending } \\
\hline & (7) & (8) & (9) & (10) & \multirow{2}{*}{$\begin{array}{c}\text { (11) } \\
\text { Healthcare }\end{array}$} \\
\hline & Age & Incapacity & Unemployment & Assistance & \\
\hline AlF & $0.687^{* *}(0.333)$ & $0.058(0.237)$ & $1.252^{* * *}(0.445)$ & $1.502^{* * *}(0.370)$ & $1.763^{* * *}(0.416)$ \\
\hline Reinforceme & $-1.343(1.306)$ & $1.485(0.956)$ & $5.029^{* * *}(1.785)$ & $5.875^{* * *}(1.513)$ & $5.262^{* * *}(1.705)$ \\
\hline AlF*Reinfor & 4.395 (3.062) & $-1.268(2.194)$ & $-11.779^{* * *}(4.320)$ & $-15.208^{* * *}(3.625)$ & $-15.063^{* * *}(3.934)$ \\
\hline Observations & 627 & 627 & 620 & 627 & 637 \\
\hline Countries & 22 & 22 & 22 & 22 & 22 \\
\hline \multirow[t]{4}{*}{$\mathrm{R}^{2}$} & 0.464 & 0.218 & 0.476 & 0.209 & 0.313 \\
\hline & \multicolumn{4}{|c|}{ Inequality reduction } & \\
\hline & (12) & (13) & (14) & (15) & \\
\hline & Age & Incapacity & Unemployment & Assistance & \\
\hline AIF & $-0.202(0.150)$ & $-0.053(0.044)$ & $0.073(0.058)$ & $0.424^{* *}(0.179)$ & \\
\hline Reinforcement & $-1.168(0.916)$ & $0.167(0.269)$ & $0.196(0.197)$ & $1.964^{* * *}(0.686)$ & \\
\hline AIF*Reinforc & $1.939(1.845)$ & $0.190(0.492)$ & $-0.803^{*}(0.485)$ & $-4.971^{* * *}(1.800)$ & \\
\hline Observations & 87 & 79 & 80 & 88 & \\
\hline Countries & 19 & 19 & 19 & 19 & \\
\hline $\mathrm{R}^{2}$ & 0.492 & 0.702 & 0.572 & 0.490 & \\
\hline
\end{tabular}

Notes: ${ }^{*} p<0.1 ;{ }^{* *} p<0.05 ;{ }^{* * *} p<0.01$. Panel-corrected standard errors in parentheses. The full set of control yariables is not reported for ease of presentation. Full estimations are detailed in the Online Appendix.

This article is protected by copyright. All rights reserved. 
Table 4. The interactive effect of diversity and income reinforcement on social security entitlements

\begin{tabular}{|c|c|c|c|c|}
\hline \multirow{3}{*}{$\square$} & \multicolumn{2}{|c|}{ Unemployment } & \multicolumn{2}{|c|}{ Sick pay } \\
\hline & (16) & (17) & (18) & (19) \\
\hline & Replacement rate & Coverage & Replacement rate & Coverage \\
\hline AIF & $-0.273^{* * *}(0.093)$ & $0.199^{* *}(0.084)$ & $-0.256^{* * *}(0.092)$ & $0.235^{* *}(0.099)$ \\
\hline Reinforcem & $-0.531^{* *}(0.209)$ & $0.501^{* *}(0.207)$ & $-0.675^{* * *}(0.169)$ & $0.757^{* * *}(0.244)$ \\
\hline AlF*Reinfor & $2.475^{* * *}(0.815)$ & $-1.865^{* *}(0.768)$ & $2.302^{* * *}(0.790)$ & $-2.278^{* *}(0.935)$ \\
\hline Observations & 628 & 556 & 637 & 551 \\
\hline Countries & 21 & 20 & 21 & 20 \\
\hline $\mathrm{R}^{2}$ & 0.098 & 0.188 & 0.076 & 0.193 \\
\hline
\end{tabular}

Notes: ${ }^{*} p<0.1 ; p<0.05 ;{ }^{* * *} p<0.01$. Panel-corrected standard errors in parentheses. The full set of control variables, with the addition of union density, is not reported for ease of presentation. Complete estimations are detailed in the Online Appendix.

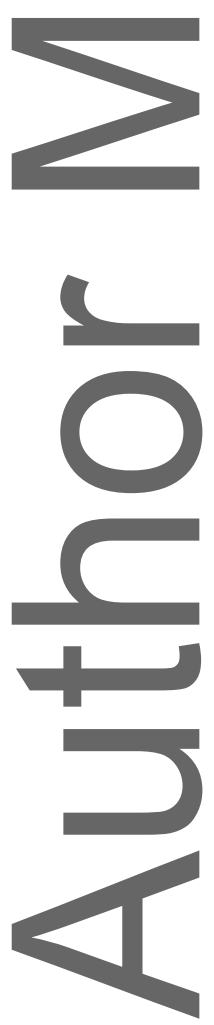

This article is protected by copyright. All rights reserved. 